\title{
A REALIDADE CONTROVERSA E ASPECTOS RELEVANTES DA LEI DE EXECUÇÃO PENAL:
}

\author{
THE CONTROVERSIAL REALITY AND RELEVANT ASPECTS OF THE LAW OF CRIMINAL \\ EXECUTION
}

Fabiano Yuji Takayanagi**

\begin{abstract}
Resumo:
O presente estudo objetiva a exposição da realidade controversa da Lei de Execução Penal, bem como salientar seus aspectos mais relevantes. Assim, serão expostos os momentos nos quais a referida Lei é aplicada, os princípios nela regentes, a suma importância dos Direitos Humanos para que os condenados sejam devidamente tratados, as críticas de falhas existentes tanto nos sistemas penitenciários, como na própria aplicação da Lei. E ainda, a situação dos presídios em oposição às invocações do corpo da legislação de execução penal.

Desta forma, tal pesquisa apontará as falhas existentes entre o real e o idealizado em um mundo político-legislativo, cujo final nem sempre é o almejado.
\end{abstract}

Palavras-chave: Lei de Execução Penal aspectos relevantes e controversos. Situação dos presídios. Direitos Humanos.

\begin{abstract}
:
The present study aims at exposing the controversial reality of Criminal law enforcement, as well as highlight your most relevant aspects. So, are exposed the moments in which the law is applied, the principles, the paramount rulers of human rights so that those convicted are properly treated, the criticism of existing flaws both in penitentiary systems, as in the law enforcement itself. And yet, the situation of prisons in opposition to invocations of the penal execution law body. In this way, such research will point the flaws that exist between the real and idealized into a legislative-political world, whose end is not always the desired.
\end{abstract}

Keywords: Criminal execution law aspects relevant and controversial. The situation of prisons. Human Rights.

Introdução

A Lei de Execução Penal promulgada no ano de 1984 foi um grande avanço ao sentenciado de uma decisão penal condenatória, pois visou sua ressocialização. Embora

\footnotetext{
Agradecimentos:

Agradeço, especialmente, ao meu grande amigo Antonio Augusto de Campos Neto, que sempre solícito e com sábias palavras proporcionou a evolução de minha pessoa.

Um cordial e caloroso agradecimento à professora Denise Auad, que me impulsionou ao gosto pela pesquisa acadêmica.

Por fim, um imprescindível agradecimento à Eliza, Yai e Ellen, que são os pilares para construção e desenvolvimento de minha fortaleza.

- Aluno da graduação da Faculdade de Direito da Universidade de São Paulo.
} 
a pena seja uma forma de atuação rigorosa na qual o Estado age sobre determinado indivíduo, restringindo sua liberdade, não se justifica a exclusão literal dessa pessoa de toda a sociedade.

Para isso, a Lei n. 7.210/84 teve como princípios norteadores os da individualização e humanização da pena, dignidade da pessoa humana, coisa julgada e vedação ao excesso de execução e intranscendência da pena. Ainda, pautando todos os procedimentos sob a égide do princípio do devido processo legal e da legalidade, com o objetivo de fornecer a condigna segurança jurídica e administrativa.

Nesse diapasão, a presente análise tendeu buscar não só os pontos primordiais concernentes à formação da Lei de Execuções Penais, como também aqueles atinentes às falhas de uma Lei de relevante importância, vez que se trata do status libertatis de um ser humano.

Por fim, será apontada, mediante as recentes reportagens de jornais de grande circulação, a lastimável situação carcerária, vez que há a desconfiguração de uma realidade formalmente pensada e posta sob a forma legal para uma realidade cruel e falsa.

\section{A Lei de Execução Penal}

A Lei de Execução Penal possui em seu corpo determinadas garantias, isto é, espécies de defesas dos direitos dos condenados, tais quais, a assistência jurídica, médica, educacional, social e material, que consistem na ênfase dada à humanização do sistema prisional, com incentivo, inclusive, de penas alternativas.

Trata-se da terceira forma processual penal precedida do processo de conhecimento e do processo cautelar, cuja principal função é o cumprimento das decisões judiciais sejam de natureza condenatórias, sejam de medidas de segurança, de forma, portanto, a servir como título executivo judicial e, ao mesmo tempo, como proteção dos sentenciados.

O tratamento dado ao preso é voltado à dignidade da pessoa humana è̀ ressocialização em sociedade após o cumprimento da pena a ele designada, consoante se verifica no art. $1^{\circ}$ : A execução penal tem por objetivo efetivar as disposições de sentença ou decisão criminal e proporcionar condições para a harmônica integração social do condenado e do internado.

Sua aplicação é posterior à sentença dada pelo magistrado, desde que se trate de uma condenação ou imposição de medida de segurança. Dessa forma, após a adoção do sistema trifásico da pena, o juiz responsável pela execução da pena irá seguir os ditames da Lei n. 7.210/84.

A finalidade da execução penal, portanto, não é a retribuição, tampouco a prevenção. Perfaz-se na possibilidade de reintegrar socialmente o condenado, segundo 
o art. $1^{\circ}$ supra transcrito. Neste sentido, a função da execução é a prevenção especial positiva.

\section{O sistema trifásico da fixação da pena}

A aplicação da pena privativa de liberdade deve seguir um procedimento trifásico, no qual o magistrado deverá adotar o seguinte caminho: a fixação da pena-base, para então, levar em consideração as circunstâncias atenuantes e agravantes, por fim, adotar as causas de diminuição e aumento de pena, conforme dita o artigo 68 do Código Penal.

Entende o ilustre Miguel Reale Júnior que a reforma ocorrida no Código Penal de 1984 tornou mais amplo o poder discricionário do juiz, acentuando a cada passo a tarefa da individualização da sanção penal, repetindo em diversos momentos os critérios de que deve lançar mão o magistrado na escolha da justa medida. ${ }^{1}$

Pode, porém, o mencionado sistema possuir menos de três fases como no caso da adoção, apenas da primeira, ou haver mais fases caso se determine a substituição da pena, porém, basicamente, cumpre ao presidente da sentença, passar pelas três fases elencadas para alcançar a fixação da pena, evidentemente, motivando cada passo adotado respeitando o art. 93, IX da Constituição Federal, sob pena de nulidade da decisão.

Destarte, o primeiro momento ocorre com adoção do art. 59 e seus incisos do Código Penal, a individualização da pena na fixação da pena-base, podendo aduzir que o juiz atendendo à culpabilidade, aos antecedentes, à conduta social, à personalidade do agente, aos motivos, às circunstâncias e conseqüências do crime, bem como ao comportamento da vítima, estabelecerá, conforme seja necessário e suficiente para reprovação e prevenção do crime.

Após, cabe ao magistrado, dentre o intervalo das penas cominadas, ou seja, a fixação da pena-base, decidir pela incidência das circunstâncias agravantes e atenuantes, elencados nos art. 61 a 67 do Código Penal.

Finalmente, influenciam as causas de diminuição e de aumento na última fase da fixação da pena e estão tipificadas caso a caso nos crimes do Código Penal. Como exemplo de diminuição: o art. 121 do Código Penal, no caso de homicídio simples, cuja pena será diminuída de um sexto a um terço, se o agente cometer o crime impelido por motivo de relevante valor social ou moral, ou sob domínio de violenta emoção, logo em seguida a injusta provocação da vítima; e de aumento, o do art. 157 , parágrafo $2^{\circ}$, do

REALE Jr., Miguel. Instituições de direito penal - parte geral. Vol. II. 2ed. Rio de Janeiro: Forense 2004, p.83. 
Código Penal, em que a pena prevista para roubo simples sofrerá aumento de um terço até metade, se a violência ou ameaça for exercida com emprego de arma de fogo.

Entendido o sistema para fixação da pena, que dá respaldo ao magistrado com o fito de proferir a sentença, faz-se necessário ao aprofundamento quanto da finalidade da sanção penal para então adentrar na execução penal.

3. A finalidade da pena

A pena pode ser definida, segundo Damásio E, de Jesus, ${ }^{2}$ como uma sanção aflitiva imposta pelo Estado, mediante ação penal, ao autor de uma infração penal, como retribuição de seu ato ilicito, consistente na diminuição de um bem jurídico, e cujo fim é evitar novos delitos.

Nesse sentido, a pena no Direito Penal, como ultima ratio, pode estar revestida de diferentes finalidades, dependendo apenas da corrente adotada, isto é, a atuação do Estado, sob a forma de um ente garantidor da paz social e protetor de bens jurídicos considerados relevantes à harmonia de uma coletividade, aplica sanções penais de cunho retributivo, ou preventivo especial, ou preventivo geral.

Quando se afirma que a pena tem um caráter retributivo, é interpretar uma sanção em retribuição à ação cometida e proibida. A Lei de Talião, cujo aforismo olho por olho, dente por dente, tinha essa conotação, pois deveria ser um mal repreendido por outro mal (é o direito à vingança com as próprias mãos). Tal sentimento de escarmento não deve ser o seio nutriente do Direito Penal.

Com a formação do Estado, detentor do poder legítimo da força, tal brocardo é vedado, uma vez que caberia ao ente máximo valer de seu vigor legal para punir o indivíduo que cometesse qualquer delito, impedindo, assim, salvo exceções, a autotutela.

A pena pode também, para alguns doutrinadores, assumir a função de prevenção especial, ou seja, nas palavras de Claus Roxin, citado por Delmanto, ${ }^{3}$ temos que a prevenção especial pode atuar de três formas: assegurando, com a prisão, a comunidade diante dos delinqüentes, intimidando o autor, por meio da pena, para que não cometa futuros delitos; e preservando-o da reincidência mediante a sua correção. Seria a idéia da ressocialização.

A jurista Janaina Conceição Pachoal ${ }^{4}$ divide essa função em duas partes: a função preventiva especial negativa, que extirparia, segregaria o indivíduo inconveniente

JESUS, Damásio E. de. Código penal anotado. 11. ed. São Paulo: Saraiva, 2001. p. 149.

DELMANTO, Celso; DELMANTO, Roberto; DELMANTO JÚNIOR, Roberto; DELMANTO, Fabio M. de Almeida. Código penal comentado. 7. ed. Rio de Janeiro: Renovar, 2007. p. 125.

4 PASCHOAL, Janaina Conceição. Direito penal: parte geral. São Paulo: Manole, 2003. p. 101-102. 
da sociedade, e a função preventiva especial positiva, que estaria relacionada às teses das escolas Correcionalista e da Defesa Social.

O caráter preventivo geral tem seu conteúdo firmado no Direito Natural e voltado para a idéia da taxatividade da Lei penal, assim, conceitua-se aos cidadãos que a pena seria uma forma de demonstrar à sociedade o melhor caminho a ser seguido, o cumprimento legal.

Dessa forma, à luz do entendimento de Delmanto, ${ }^{5}$ o legislador de 84 adotou a denominada teoria unitária, atribuindo à pena tríplice função: de retribuição, de prevenção especial e de prevenção geral. Deve-se fazer uma leitura do art. 59 do Código Penal concomitante com o art. $1^{\circ}$ da Lei de Execuções Penais para se ter uma noção de que a sanção penal tem a função de, uma vez estabelecida pelo juiz, conforme seja necessário e suficiente para a reprovação e prevenção do crime, ter-se-á o objetivo final, na sua execução, a ressocialização do penalmente sentenciado e, passada essa parte, o fim precípuo seria atingido: a reintegração social do condenado.

\section{Os Princípios ${ }^{6}$ da Lei de Execução Penal}

\subsection{Princípio da individualização da pena ${ }^{7}$}

DELMANTO, Celso; DELMANTO, Roberto; DELMANTO JÚNIOR, Roberto; DELMANTO, Fabio M. de Almeida. Código penal comentado. 7ed. Rio de Janeiro: Renovar, 2007. p. 126.

6 A etimologia da palavra "princípios" tem, segundo Ivan Horcaio, o significado de regra, preceito, razão primária. (HORCAIO, Ivan. Dicionário Juridico Referenciado. São Paulo: Primeira Impressão, 2006. p. 858). Um maior aprofundamento sobre a palavra está no estudo de Robert Alexy, que os conceituou como normas que ordenam que algo seja realizado no maior medida possível dentro das possibilidades jurídicas e fáticas existentes. Princípios são, por conseguinte, "mandamentos de otimização", que são caracterizados por poderem ser satisfeitos em graus variados e pelo fato de que a medida devida de sua satisfação não depende somente das possibilidades fáticas, mas também das possibilidades jurídicas. Porém, nesse mesmo estudo, foi-se explicitado que tal palavra não se deve confundir com regras, pois estas são sempre satisfeitas ou não satisfeitas. Assim, se uma regra está valendo, não há o que se discutir, deve se fazer exatamente o que ela demanda, sem mais, nem menos. Regras contêm, portanto, "determinações" no âmbito daquilo que é fática e juridicamente possível. Dessa forma, a diferença básica entre princípios e regras, nos ensinamentos de Alexy está na qualificação e não uma distinção de grau. Essa diferença tem suma importância ao se adotar a teoria das colisões demonstrada pelo mesmo jurista. De forma bem sucinta, a colisão entre regras é resolvida mediante a introdução de uma cláusula de exceção que elimine o conflito, ou se, ao menos, uma das regras for declarada inválida, logo extirpada do ordenamento jurídico. Em esteira diametralmente oposta, a colisão de princípios tem solução diversa, pois se dois princípios não convivem simultaneamente, deve-se haver um sopesamento, isto é, os "pesos"entre eles devem ser levados em consideração e não são analisadas a validade. (ALEXY, Robert. Teoria dos direitos fundamentais. Tradução Luís Virgílio Afonso da Silva. São Paulo: Malheiros, 2008. p. 90-95).

7 Segundo o Superior Tribunal de Justiça, a Constituição da República recepcionou o sistema progressivo de cumprimento de pena, constante do Código Penal e da Lei de Execução Penal, negá-lo ao condenado por crime hediondo gera descabida afronta aos princípios da humanidade das penas e da sua individualização. Recurso especial parcialmente provido. (REsp 775351 - RS - $6^{\mathrm{a}}$ T. - Rel. Min. Paulo Medina - DJU 02.05.2006, p. 405). O sentenciado que cumpre pena em regime semi-aberto e pratica falta grave, deverá ter o seu regime regredido para o regime imediatamente anterior - Fechado, sob pena de ferir o princípio da individualização da pena na fase de execução. Recurso improvido. (TAMG - AgCr 0379479-8 - 72077 - 2a C. - Rel. Des. Antônio 
$\mathrm{O}$ art. $1^{\circ}$ da Lei de Execução Penal deixa patente o tratamento individual do condenado e do internado, pois busca a ressocialização do condenado de modo que cada caso seja tratado de forma única.

A individualização da pena é um direito fundamental, conforme dispõe o art. $5^{\circ}$, incisos XLV e XLVI da Carta Maior: a lei regulará a individualização da pena (...) e nenhuma pena passará da pessoa do condenado, podendo a obrigação de reparar o dano e a decretação do perdimento de bens ser, nos termos da lei, estendidas aos sucessores e contra eles executadas, até o limite do valor do patrimônio transferido, respectivamente.

Trata-se da responsabilidade individual na qual ninguém poderá responder criminalmente além dos limites de sua culpabilidade e, por essa razão, a morte extingue automaticamente a punibilidade, segundo o art. 107, inciso I do Código Penal.

É igualmente a efetivação de um direito e garantia fundamental prescrito no artigo $5^{\circ}$ inciso XLVI e atendimento à isonomia, nos dizeres de Gustavo Octaviano Diniz Junqueira, que isonomia porque apenas quando reconhecidas as desigualdades (peculiaridades individualizadoras) é possivel tratar cada qual de acordo com seus méritos e deméritos. A individualização das penas, assim, que tem por base constitucional, é especificação do postulado da isonomia. ${ }^{8}$

Aduz a jurista Carmem Silvia de Moraes Barros que a execução penal, bem como as demais fases de individualização da pena, está estritamente vinculada aos princípios e garantias do Estado de direito e à política criminal definida pela Constituição. $^{9}$

Alexandre de Moraes, por sua vez, define que o referido princípio exige uma estreita correspondência entre a responsabilização da conduta do agente e a sanção a ser aplicada, de maneira que a pena atinja suas finalidades de prevenção e repressão. Assim, a imposição da pena depende do juízo individualizado da culpabilidade do agente (censurabilidade de sua conduta).$^{10}$

A Constituição Federal quando dispõe sobre a individualização da pena, remete a determinadas fases, quais sejam, a fase legislativa. De acordo com tal momento, para o processo de execução e individualização se concretizar, deve haver uma lei

Armando dos Anjos - J. 11.02.2003). Contra, entendendo que não cabe ao juiz das execuções criminais mais que a mera realização da sentença: PENA - EXECUÇÃO - INDIVIDUALIZAÇÃO - INEXISTÊNCIA EM TAL FASE PROCESSUAL Mera execução da pena emposta no juízo de conhecimento. Ocorrência de

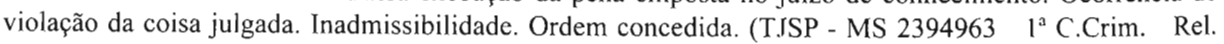
Des. Fortes Barbosa - J. 17.11.1997).

8 JUNQUEIRA, Gustavo Octaviano Diniz; FULLER, Paulo Henrique Aranda. Legislação penal especial. 5. ed. São Paulo: Premier Máxima, 2008. p. 28.

9 BARROS, Carmem Silvia de Moraes. A individualizução da pena na execução penal. São Paulo: Revista dos Tribunais, 2001. p. 129.

10 MORAES, Alexandre de. Direitos humanos fundamentais: teoria geral. 8. ed. São Paulo: Atlas, 2007. p. 240-241. 
regulamentando a individualização (Exemplo: homicídio deve haver pena maior do que de roubo, que tem que ser maior do que de furto e assim por diante. E dentro de um mesmo delito, é necessário um elastério, pois existem roubos e roubos).

O segundo momento, a fase judicial, existe a figura do Juiz que fixa a pena com base no art. 59 do Código Penal, cujo conteúdo principal é a culpabilidade. "Necessário e suficiente para a prevenção e reprovação do delito". A prevenção mencionada não deve ser geral, pois esta deve advir da pena cominada, a aplicada, portanto, é a prevenção especial. E reprovação pela teoria retributiva.

O Supremo Tribunal Federal, no julgamento do RHC, 93.308-4 - RS, $1^{\text {a }}$ Turma, rel. Min. Carlos Britto, j. 03-02-2009, afirmou ser uma questão das mais trabalhosas a definição da pena adequada ao caso concreto. Para a dosimetria da pena, deve o julgador ter uma cuidadosa ponderação dos efeitos étnico-sociais da sanção penal e das garantias constitucionais, especialmente a garantia da individualização do castigo.

São exemplos da real aplicação do princípio da individualização da pena sob a forma da Lei a necessidade de separação dos presos, os diversos tipos de regimes para o cumprimento de pena, a progressão, a regressão, o livramento condicional, entre outros casos.

É, portanto, um princípio que ampara o condenado de forma a ser devidamente tratado caso a caso e delimita a atuação do Estado protegendo o direito individual. Além disso, tem-se a plena consciência de que os seres humanos são diferentes entre si, razão pela qual a execução não pode ser homogênea. Deve-se, ainda, haver critérios para a separação de tipos de cumprimentos. Individualizar a pena, na execução, consiste em dar a cada preso as oportunidades e os elementos necessários para lograr sua reinserção social, posto que é pessoa, ser distinto, conforme o jurista Julio Fabrinni Mirabete. ${ }^{11}$

\subsection{Princípio da humanização das penas e a dignidade da pessoa humana}

A humanização das penas, nos ensinamentos de Gustavo Octaviano Diniz Junqueira, varia de acordo com o contexto histórico, seguindo frequentemente a evolução, concomitante à compreensão do homem como fim, possuidor de uma intangível dignidade.

A Lei Maior em seu art. $5^{\circ}$ inciso XLVII, veda a pena de morte, salvo em caso de guerra declarada, nos termos do art. 84, XIX; de caráter perpétuo; de trabalhos forçados; de banimento; cruéis, justamente, em respeito a um princípio fundamental norteador dessa Lei que é o da dignidade da pessoa humana.

O princípio da dignidade da pessoa humana tem sua importância há tempos, a saber, na Declaração Universal dos Direitos Humanos, adotada e proclamada

"MIRABETE, Julio Fabbrini. Execução penal. São Paulo: Atlas, 2004. p. 48-49. 
pela Resolução n. 217 A (III) da Assembléia Geral das Nações Unidas, em 1948, em cujo preâmbulo invoca tal princípio como sendo inerente a todos os membros da família humana e como fundamento da liberdade, da justiça e da paz mundial.

As palavras ilustres do jurista José Afonso da Silva definem a dignidade da pessoa humana como sendo um valor supremo que atrai o conteúdo de todos os direitos fundamentais do homem, desde o direito à vida. É uma espécie de referência constitucional unificadora de todos os direitos fundamentais, trata-se de uma obrigação a uma densificação valorativa que tenha em conta o seu amplo sentido normativo-constitucional e não uma qualquer idéia apriorística do homem, não podendo reduzir-se o sentido da dignidade humana à defesa dos direitos tradicionais, esquecendo-a nos casos de direitos sociais, ou invocá-la para construir "teoria do núcleo da personalidade" individual, ignorando-a quando se trate de garantir as bases da existência humana. ${ }^{12}$

Nas lições de Alexandre de Moraes, de seu lado, haver-se-ia uma dupla concepção do princípio. A primeira no sentido de um direito individual protetivo, seja em relação ao Estado, seja em relação aos demais indivíduos. $\mathrm{Na}$ segunda concepção, tem-se o estabelecimento de um dever fundamental de tratamento igualitário dos próprios semelhantes. ${ }^{13}$

Ainda, encontra-se outro direito e garantia fundamental, o disposto no artigo $5^{\circ}$, inciso XLIX, da Carta Magna, que assegura aos presos o respeito à sua integridade física e moral. São os direitos humanos fundamentais ligados à execução da pena, cujas palavras de Alexandre de Moraes explicam que a Constituição Federal, ao proclamar o respeito à integridade física e moral dos presos, em que pese à natureza das relações jurídicas estabelecidas entre a Administração Penitenciária e os sentenciados a penas privativas de liberdade, consagra a conservação por parte dos presos de todos os direitos fundamentais conhecidos à pessoa livre, com exceção, obviamente, daqueles incompativeis a condição peculiar do preso. ${ }^{14}$

Diante disso, entende-se que o sentenciado, seja por uma condenação, seja por a imposição de uma medida de segurança, não perde a condição de ser humano. Tem ele as garantias dignidade da pessoa humana a seu favor.

4.3. Princípio da coisa julgada e da vedação ao excesso de execução

É uma forma de limitação dos dispostos na sentença ${ }^{15}$ e abarcado pela coisa julgada, assim, a execução penal não irá além da condenação sofrida.

12 SILVA, José Afonso da. Curso de direito constitucional positivo. 24. ed. São Paulo: Malheiros, 2005. p. 105.

13 MORAES, Alexandre de. Direitos humanos fundamentais: teoria geral. 8. ed. São Paulo: Atlas, 2007. p. 46.

14 Id. Ibid., p. 247-248.

15 Segundo Fernando Capez, a sentença é uma manifestação intelectual lógica e formal emitida pelo Estado, 
Vislumbra-se no caso atual, exposto por Gustavo Octaviano Junqueira, em que é considerado ilegal e passível de imediata correção a violação de liberdade do condenado acima do admitido na decisão condenatória, ou mesmo do que consta das decisões em sede de execução penal, em cumprimento ao referido princípio do respeito à coisa julgada. ${ }^{16}$ Esta nada mais é que uma decisão imutável e irrevogável.

O fundamento político da coisa julgada, segundo Fernando da Costa Tourinho Filho, é que não mais havendo possibilidade de recursos, ou porque houve preclusão, ou porque já se esgotaram todos os meios de impugnação, a sentença tornase irreversível, imutável. O fundamento político da coisa julgada descansa, pois, na necessidade da paz social, com a consequente manutenção e segurança jurídicas. ${ }^{17}$

Deste modo, tem-se o estrito cumprimento da legalidade das penas, isto é, elas impõem as sanções decorrentes do cometimento dos ilícitos penais, bem como estão expressas, caso a caso, mediante a motivação da decisão penal. Logo, não se pode ultrapassar a condenação imposta, já abarcada pelo princípio da coisa julgada, com conseqüências funestas do seu descumprimento: a instabilidade da ordem jurídica.

Tal princípio é defendido pelos Tribunais, conforme pode-se constatar no seguinte julgado: ainda que haja ofensa a preceito legal, não há como prejudicar o apenado e remetê-lo ao cumprimento da pena em regime mais gravoso quando, há muito, já possuía o direito para a progressão ao regime aberto, sob pena de ocorrer excesso de execução (TJSC HC 20060158079 - $1^{\text {a }}$ C.Crim. - Rel. Des. Amaral e Silva DJ 28.07.2006).

Em suma, assegura-se a execução da pena nos limítrofes declarados na sentença penal condenatória impedindo que o juiz da execução modifique-a em prejuízo do sentenciado, é a harmonização da segurança jurídica.

\subsection{Princípio da personalidade da pena ou intranscendência da pena}

Remete-se tal princípio, novamente, ao art. $5^{\circ}$, inciso XLV da Carta Maior, que dispõe: nenhuma pena passará da pessoa do condenado, podendo a obrigação de

por meio de seus órgãos jurisdicionais, com a finalidade de encerrar um conflito de interesses, qualificado por uma pretensão resistida, mediante a aplicação do ordenamento legal ao caso concreto. É a consumação da função jurisdicional em que é aplicada a lei no caso concreto, tendo a busca do fim de uma controvérsia. (CAPEZ, Fernando. Curso de processo penal. 16. ed. São Paulo: Saraiva, 2009. p. 460). Nos ensinamentos de Gustavo Octaviano Junqueira, sentença é ato normativo que resolve a situação concreta, em substituição à vontade das partes. $\mathrm{O}$ ato normativo genérico não pode prevalecer sobre ela, sendo possivel, no máximo, havendo remédio processual, sua reforma (JUNQUEIRA, Gustavo Octaviano Diniz e FULLER, Paulo Henrique Aranda. Legislação Penal Especial. Vol I. 5ed. São Paulo: Premier Máxima, 2008, p.30).

16 JUNQUEIRA, Gustavo Octaviano Diniz; FULLER, Paulo Henrique Aranda. op. cit., p. 29-30.

17 TOURINHO FILHO, Fernando da Costa. Manual de processo penal. 10. ed. São Paulo: Saraiva, 2008. p. $770-772$. 
reparar o dano e a decretação do perdimento de bens ser, nos termos da lei, estendidas aos sucessores e contra eles executadas, até o limite do valor do patrimônio transferido. A responsabilidade deve ser personalizada, individual, em que ninguém pode responder criminalmente além dos limites da própria culpabilidade.

Dessa forma, a pena não irá se estender sobre terceiros como cônjuge, filhos, dependentes do preso, familiares. Nos dizeres de Carmen Silvia de Moraes Barros, a personalidade determina que a pena seja dirigida àquela pessoa individualmente considerada, não podendo ultrapassá-la; que todo aquele que cumpre pena privativa de liberdade seja devidamente identificado e registrado e que sejam consignados os motivos da prisão, a autoridade que a determinou, a hora e o dia em que se deu a entrada no sistema prisional. ${ }^{18}$

Se a pena não pode passar da pessoa do condenado, a controvérsia surge na pena de multa após o falecimento do condenado. Pode-se, de um lado, defender a cobrança dos herdeiros pelo fato de ter se transformado em dívida de valor, de outro, adotar que 0 caráter de pena ainda persiste, portanto, deve-se respeitar o princípio da intranscendência, que, de fato, parece mais plausível.

Quanto ao perdimento de bens, se há a morte do acusado, tem-se a posição do seguinte julgado: Se a medida cautelar de seqüestro fundamenta-se no fato de que, em caso de eventual condenação, os bens objeto do crime sofreriam pena de perdimento em favor da União, bem como serviriam para o pagamento do prejuizo causado pelo delito praticado, a morte do acusado, que extingue a punibilidade, faz com que a constrição imposta perca efeito. A pena de perdimento e o dever de reparar o dano causado pelo delito decorrem da condenação, o que não se verificará em razão do falecimento do réu. Questão de ordem acolhida para liberar os bens seqüestrados dos falecidos. TRF $4^{a}$ REGIÃO QUESTÃO DE ORDEM NA ACR N. 2003.71.08.006855-2/RS (DJU 09.06.2004, Rel LUIZ FERNANDO WOWK PENTEADO.

Dessa forma, o princípio da intrascendência permite que haja maior segurança jurídica e faz com que seja um direito e garantia fundamental cumprido para que não se responsabilize além da culpabilidade do apenado.

\subsection{Princípio do devido processo legal}

Trata-se do princípio em que nenhuma sanção pode ser imposta ao condenado sem a instauração do devido procedimento disciplinar (falta disciplinar) ou do devido procedimento judicial (regressões, revogações, conversões, etc.). $\mathrm{O}$ devido

\footnotetext{
18 BARROS, Carmem Silvia de Moraes. A individualização da pena na execução penal. São Paulo: Revista dos Tribunais, 2001. p. 132-133.
} 
processo legal abrange o contraditório e a ampla defesa, assim, o sentenciado poderá defender-se e terá direito à assistência de um Defensor, em especial nos procedimentos judiciais (art. 194/197 da LEP).

No tocante aos procedimentos meramente administrativos disciplinares (para imposição de sanções por faltas), o STF decidiu, por meio de Súmula Vinculante (n. 05) que "a falta de defesa técnica por Advogado no processo administrativo disciplinar não ofende a Constituição"

\subsection{Princípio da legalidade}

É um princípio constitucional elencado no art. $5^{\circ}$, inciso XXXIX, que define a inexistência de crime sem lei anterior que o defina, nem pena sem prévia cominação legal. Por força desse importante princípio, todo o procedimento executório da lei deve se pautar em previsões anteriormente estabelecidas.

Portanto, apenas caberá a regressão de regime, a revogação de benefícios e a aplicação de faltas disciplinares em hipóteses previamente elencadas em lei. Também é o respeito à anterioridade da Lei penal no art. $1^{\circ}$ do Código Penal.

\section{A natureza jurídica da Lei de Execução Penal}

A presente Lei n. 7.210/84 não tem pacificada sua natureza jurídica. De um lado, a doutrina afirma ser a Lei de Execuções Penais de caráter administrativo, de outro, aduz ser de caráter jurisdicional Por fim, há o meio termo exclamando ser de caráter misto.

Independente do posicionamento, deve-se orientar pelos ditames expostos no artigo $5^{\circ}$ incisos LIV e LV da Carta Magna, em que ninguém será privado da liberdade ou de seus bens sem o devido processo legal; e aos litigantes, em processo judicial ou administrativo, e aos acusados em geral são assegurados o contraditório e ampla defesa, com os meios e recursos a ela inerentes, respectivamente. Portanto, o devido processo legal, o contraditório e a ampla defesa deverão estar presentes, sem exclusão de qualquer um desses princípios, em qualquer tipo de procedimento, quer seja administrativo, ou judicial.

Dessa forma, a corrente defensora da natureza jurídica administrativa da Lei entende que não haveria processo tampouco aplicação da jurisdição. ${ }^{19}$ Seria uma simples atividade administrativa, cujo único objetivo é de realizar concretamente o que ficou decidido na sentença condenatória, conforme explica Antonio Magalhães Gomes Filho. ${ }^{20}$

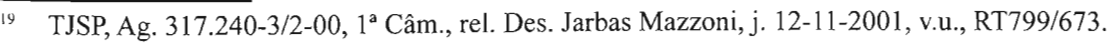

20 GOMES FILHO, Antonio Magalhães. A motivação das decisões penais. São Paulo: Revista dos Tribunais, 2001, pp. 235-236.
} 
Por outro lado, a corrente jurisdicional entende que haveria jurisdição durante todo o procedimento executório, cujo Poder Judiciário estaria atuante constantemente, com o fito de solucionar os conflitos de interesse surgidos entre o Ministério Público, em prol da sociedade, e o sentenciado. ${ }^{21}$

Corrobora a natureza jurisdicional o fato do respeito aos valores democráticos da Constituição. O ilustre Gustavo Octaviano Diniz Junqueira ${ }^{22}$ defende que, em um Estado de Direito, é necessário que um Poder independente possa controlare limitar os atos do outro Poder, assim, o Poder Legislativo regula e limita em abstrato os atos da natureza penitenciária, cabendo o Poder Judiciário a solução de conflitos entre a liberdade e o poder de punir.

E ainda acrescenta que essa é a evolução natural da universalidade da jurisdição invocando a Constituição Federal em seu art. $5^{\circ}$ inciso XXXV: a lei não excluirá da apreciação do Poder Judiciário lesão ou ameaça a direito.

Nesse mesmo diapasão, entende Carmen Silvia de Moraes Barros que o processo de execução penal teria natureza jurisdicional, cujo condenado, como parte ou sujeito da relação processual, é titular de direitos, sendo-lhe assegurado o direito a um processo de execução penal com todas as garantias. ${ }^{23}$

Todavia, é de se perceber que no Direito Brasileiro, a natureza jurídica da execução penal é a mista, ou seja, em partes predominará o âmbito administrativo e em outras a esfera jurisdicional.

Essa natureza jurídica mista é defendida pela grande jurista Ada Pellegrini Grinover, citada por Renato Marcão ${ }^{24}$ em que: não se nega que a execução penal é atividade complexa, que se desenvolve, entrosadamente, nos planos jurisdicional e administrativo. Nem se desconhece que dessa atividade participam dois Poderes estaduais: o Judiciário e o Executivo, por intermédio, respectivamente, dos órgãos jurisdicionais e dos estabelecimentos penais. Portanto, temos determinadas normas pertencentes ao direito processual, como o caso de solução de incidentes, e determinadas normas regulando a execução propriamente dita na esfera do direito administrativo.

Conclui-se, conforme as Súmulas ${ }^{25}$ das Mesas de Processo Penal do Departamento de Direito Processual da Faculdade de Direito da Universidade de São

TJSP, Ag. 317.240-3/2-00, $1{ }^{a}$ Câm., rel. Des. Jarbas Mazzoni, j. 12-11-2001, v.u., RT799/673.

22 JUNQUEIRA, Gustavo Octaviano Diniz; FULLER, Paulo Henrique Aranda. Legislaçâo penal especial. 5. ed. São Paulo: Premier Máxima, 2008. v, 1, p. 30.

23 BARROS, Carmem Silvia de Moraes. A individualização da pena na execuçâo penal. São Paulo: Revista dos Tribunais, 2001. p. 134.

24 MARCÃO, Renato. Lei de execução penal anotada e interpretada. 3. ed. Rio de Janeiro: Lumen Juris, 2009. p. 1-2.

25 Súmula n. 39 - A execução penal é atividade complexa que se desenvolve, entrosadamente, nos planos jurisdicional e administrativo.

Súmula n. 40 - Guarda natureza administrativa a expiação da pena. É objeto do processo de execução, 
Paulo (Mesas compostas pelo Prof. Dante Busana, Profa. Ada Pellegrini Grinover e Prof. Oscar Xavier de Freitas), que a tese de natureza jurídica da Execução Penal seja a mista.

\section{A Lei de Execução Penal e o respeito aos Direitos Humanos}

As atrocidades ocorridas na Segunda Guerra Mundial despertaram a necessidade de se projetar um novo sistema de proteção dos direitos da pessoa humana contra as possíveis arbitrariedades dos Estados e dos indivíduos que agem em seu nome. Assim, na data de 10 de dezembro de 1948, foi adotada e proclamada a Resolução n. 217 A (III) pela Assembléia Geral das Nações Unidas e ratificada pelo Brasil, nesse mesmo dia, a Declaração Universal dos Direitos Humanos.

Pode-se entender dessa Declaração como fruto da Carta da ONU. Esta Carta em seu art. $1^{\circ}$ elencou, como um dos objetivos das Nações Unidas, a realização da cooperação internacional, resolvendo os problemas internacionais de caráter econômico, social, cultural ou humanitário, promovendo e estimulando o respeito pelos direitos do homem e pelas liberdades fundamentais para todos, sem distinção de raça, sexo, língua ou religião. Invocando tal artigo, buscou-se fazer valer a igualdade de direito tanto para homens quanto para mulheres independentemente do tamanho de suas nações. Foi dada importância no âmbito global pelo respeito aos direitos humanos.

Assim, quando a Declaração Universal dos Direitos Humanos ${ }^{26}$ explicita em seus art. $1^{\circ}$ - Todas as pessoas nascem livres e iguais em dignidade e direitos. São dotadas de razão e consciência e devem agir em relação umas às outras com espírito de fraternidade; $2^{\circ}$ - Toda pessoa tem capacidade para gozar os direitos e as liberdades estabelecidas nesta Declaração, sem distinção de qualquer espécie, seja de raça,

guardando natureza jurisdicional, a tutela tendente à efetivação da sanção penal, inclusive com as modificações desta, decorrentes da cláusula "rebus sic stantibus", ínsita na sentença condenatória.

Súmula n. 41 -Em toda e qualquer execução penal, há pelo menos dois momentos jurisdicionais: seu início e seu encerramento.

Súmula n. 42 -No curso de toda e qualquer execução penal, podem, a qualquer momento, ocorrer fenômenos processuais, sempre que o Juiz for chamado a julgar, exercendo então a função jurisdicional em toda a sua plenitude.

Súmula n. 43 - Esses fenômenos processuais não se restringem aos denominados "incidentes de execução"(sursis e livramento condicional), mas se estendem a todos os outros, como o excesso ou desvio de execução, as modificações da pena privativa de liberdade, a unificação de penas, a reabilitação, a cessação antecipada das medidas de segurança, a conversão da pena pecuniária em pena privativa de liberdade, a revogação do sursis ou do livramento condicional etc.

Súmula n. 44 - Como em todo processo, entendido como relação jurídico-processual tríplice, o processo de execução penal é processo de partes, que assegura ao sentenciado as garantias do "devido processo legal", decorrente diretamente da Constituição, mesmo no silêncio dos Códigos.

26 Biblioteca Virtual de Direitos Humanos, da Comissão de Direitos Humanos da Universidade de São Paulo (http://www.direitoshumanos.usp.br/index.php/Declaração-Universal-dos-Direitos-Humanos/declaracaouniversal-dos-direitos-humanos.html). 
cor, sexo, lingua, religião, opinião política ou de outra natureza, origem nacional ou social, riqueza, nascimento, ou qualquer outra condição; $4^{\circ}$ - Ninguém será mantido em escravidão ou servidão; a escravidão e o tráfico de escravos serão proibidos em todas as suas formas; $5^{\circ}$ Ninguém será submetido à tortura, nem a tratamento ou castigo cruel, desumano ou degradante; $7^{\circ}$ Todos são iguais perante a lei e têm direito, sem qualquer distinção, a igual proteção da lei. Todos têm direito a igual proteção contra qualquer discriminação que viole a presente Declaração e contra qualquer incitamento a tal discriminação; $10^{\circ}$ - Toda pessoa tem direito, em plena igualdade, a uma audiencia justa e pública por parte de um tribunal independente e imparcial, para decidir sobre seus direitos e deveres ou do fundamento de qualquer acusação criminal contra ele; $24^{\circ}$ - Toda pessoa tem direito a repouso e lazer, inclusive a limitação razoável das horas de trabalho e a férias periódicas remuneradas; $27^{\circ}, \S 1^{\circ}$ - Toda pessoa tem o direito de participar livremente da vida cultural da comunidade, de fruir as artes e de participar do processo cientifico e de seus beneficios, nada mais são que exemplos de uma concretização da essência já buscada pela Carta da ONU.

A Lei de Execução Penal, por sua vez, incorporou, em seus princípios norteadores, tais direitos humanos, como foi possível comprovar no item anterior.

Ademais, é necessário o respeito aos Direitos Humanos em fase da Execução Penal, não só pelo fato do Brasil ter aderido à Declaração, mas também por causa da positivação dos Direitos Humanos sob a forma dos direitos e garantias fundamentais estabelecidos na Constituição Federal Brasileira de 1988.

O grande jurista Canotilho, citado por Alexandre de Moraes, declara a importância e finalidade dos direitos humanos fundamentais: a função de direito de defesa dos cidadãos sob uma dupla perspectiva: (1) constituem, num plano juridico-objectivo, normas de competência negativa para os poderes públicos, proibindo fundamentalmente as ingerências destes na esfera juridica individual; (2) implicam, num plano juridicosubjectivo, o poder de exercer positivamente direitos fundamentais (liberdade positiva) $e$ de exigir omissões dos poderes públicos, de forma a evitar agressões lesivas por parte dos mesmos (liberdade negativa). ${ }^{27}$

A forma positivada dos direitos humanos fundamentais ${ }^{28}$ foi uma maneira de evitar possíveis arbitrariedades do Estado, que possui o legítimo uso da força, em face

27 MORAES, Alexandre de. Direitos humanos fundamentais: teoria geral. 8. ed. São Paulo: Atlas, 2007. p. 2.

28 São as características dos direitos fundamentais brasileiros, nos ensinamentos do jurista José Afonso da Silva, a historicidade, isto é, são históricos como o direito. Eles apareceram com revolução burguesa e evoluem, ampliam-se com o correr dos tempos; inalienabilidade, não podem ser objeto de transferência, negociação, uma vez que não são de conteúdo econômico-patrimonial. Se a ordem constitucional os confere a todos, deles não se pode desfazer, porque são indisponíveis; imprescritibilidade, eles simplesmente existem na ordem jurídica, não deixam de serem exigiveis. Pois a prescrição é um instituto juridico que somente atinge, coarctando, a exigibilidade dos direitos de caráter patrimonial, não a exigibilidade de 
de seus cidadãos com suas garantias explícitas em Lei. São raras as exceções nas quais o Ente Maior pode exercer seu poderio, a exemplo, a pena de morte em caso de guerra declarada, nos termos do art. 84, IX da Lei Máxima (art. 5, inciso XLVII, alínea "a"), conforme citado anteriormente.

A Carta Republicana a fim de tornar imutáveis esses direitos e garantias fundamentais impôs o art. 60, parágrafo $4^{\circ}$, as cláusulas pétreas, para evitar qualquer tipo de modificação de Lei em desrespeito aos temas basilares do Estado Democrático de Direito (como os direitos humanos positivados).

Nesse sentido, uma Lei de Execução Penal incongruente com os direitos humanos é o mesmo que afrontar explicitamente à Carta Magna brasileira, é ser inconstitucional e inaplicável. Felizmente, tal desacordo inexiste, pois em seus princípios iluminadores foram abarcados elementos constitucionais, com o fito de trazer a segurança jurídica aos sentenciados submetidos à execução da pena.

Outro importante tratado internacional que envolve os Direitos Humanos é o Pacto de San José da Costa Rica (ou Convenção Americana de Direitos Humanos $\mathrm{CADH}$ ). Seu conteúdo é um grande código dos direitos civis e políticos das Américas e, ainda, protege amplamente os direitos humanos dos indivíduos, principalmente os latinos. No Brasil, a adesão ao Pacto ocorreu em 1992 e sua promulgação, pelo Decreto 678, em 6 de novembro do mesmo ano.

São alguns direitos protegidos pela Convenção Americana dos Direitos Humanos $^{29}$ os direitos à vida, à integridade pessoal, à liberdade pessoal, às garantias

direitos personalíssimos, ainda que não individualistas, como é o caso. Se são sempre exercíveis e exercidos, não há intercorrência temporal de não exercício que fundamente a perda da exigibilidade pela prescrição; irrenunciabilidade, os direitos fundamentais não podem ser renunciados. Alguns deles podem até não ser exercidos, pode-se deixar de exercê-los, mas não se admite sejam renunciados.

29 A maior discussão acerca da Convenção repousa sobre o seu status hierárquico, vez que a Emenda Constitucional 45 de 2004 incluiu, na Constituição Federal de 1988, o parágrafo $3^{\circ}$ do artigo $5^{\circ}$, muito embora já existisse o parágrafo $2^{\circ}$ Vejamos: Artigo $5^{\circ} \S 2^{\circ}$. Os direitos e garantias expressos nesta Constituição não excluem outros decorrentes do regime e dos princípios por ela adotados, ou dos tratados internacionais em que a República Federativa do Brasil seja parte; $\S 3^{\circ}$ Os tratados e convenções internacionais sobre direitos humanos que forem aprovados, em cada Casa do Congresso Nacional, em dois turnos, por três quintos dos votos dos respectivos membros, serão equivalentes às emendas constitucionais. Pois bem, entende uma parcela da doutrina que os tratados internacionais sobre direitos humanos anteriores à EC 45 têm a equivalência de leis ordinárias. Nesse sentido, defende Alexandre de Moraes em que os tratados ingressariam, uma vez aprovadas pelo Poder Legislativo e promulgadas pelo Presidente da República, como atos normativos infraconstitucionais, logo seriam subordinados em sua integralidade às normas constitucionais. Aduz ainda o jurista que não existe hierarquia entra as normas ordinárias de direito interno e as decorrentes de atos ou tratados internacionais. A ocorrência de eventual conflito entre essas normas será resolvida ou pela aplicação do critério cronológico, devendo a norma posterior revogar a norma anterior, ou pelo princípio da especialidade (MORAES, Alexandre de. Direitos humanos fundamentais: teoria geral. 8. ed. São Paulo: Atlas, 2007. p. 316).

Essa foi a posição assumida pelo Ministro Cunha Peixoto do Supremo Tribunal Federal no julgamento do Recurso Extraordinário n. 80.004/SE (RTJ 83/809), quando em seu voto adota a igualdade de força entre normas ordinárias e tratados internacionais de direitos humanos (RTJ 83/817), embora tenha sido o voto 
judiciais, à proteção da honra e da dignidade, à proteção da família, à igualdade perante a lei, econômicos, sociais e culturais. Além disso, o tratado explicita os meios de proteção desses direitos com esclarecimentos dos órgãos competentes, da comissão interamericana de direitos humanos e da corte interamericana de direitos humanos.

O posicionamento mais adequado, quanto ao status hierárquico do tratado de direitos humanos anterior à Emenda Constitucional de 45/04, está na consideração

vencido do Ministro Xavier de Albuquerque contrário à decisão (RTJ 83/813).

Uma corrente intermediária adotada pelo Ministro Sepúlveda Pertence, acerca do debate em tela, pois defende o grande jurista a existência de uma hierarquia supralegal, mas infraconstitucional, dos tratados sobre direitos humanos, conforme o julgado RHC n. 79.785/RJ.

Nessa mesma seara, o Ministro Cezar Peluso em seu relatório, no julgado RE 466.343/SP, onde se debatia sobre a impossibilidade da prisão civil na alienação fiduciária em garantia, também se conceituou o tratado de direitos humanos como um direito supralegal. Assim, a norma supralegal seria apenas modificável se houvesse outra Convenção revogando a matéria da norma anterior ou se viesse uma Emenda Constitucional tratando sobre Direitos Humanos, porém, em se tratando de direitos humanos, temos a proteção via cláusula pétrea do artigo 60, parágrafo $4^{\circ}$ da Carta Magna, portanto, para que essa Emenda Constitucional revogue algo do tratado versando sobre direitos humanos, deve ser matéria não tratada explicitamente nos direitos e garantias fundamentais, como por exemplo o princípio do duplo grau de jurisdição.

Uma terceira corrente começou a se firmar, inclusive, no mesmo julgado RE 466.343/SP, em que o Ministro Celso de Mello manifestou-se pela tese da hierarquia constitucional dos tratados de direitos humanos somente para os ratificados antes da EC 45 de 2004.

Os juristas Luiz Flávio Gomes e Valério de Oliveira Mazzuoli defendem que os tratados de direitos humanos ratificados pelo Brasil têm índole e nível constitucionais, quer sejam anteriores ou posteriores à EC 45/2004 (GOMES, Luiz Flávio; MAZZUOLI, Valério de Oliveira. Comentários à Convenção Americana sobre Direitos Humanos. Pacto de San José da Costa Rica. 2. ed. São Paulo: Revista dos Tribunais, 2009. v. 4 , p. 16). Ainda concluem que todos os tratados que formam o "corpus" juris convencional dos direitos humanos de que um Estado é parte servem como paradigma ao controle de convencionalidade das normas infraconstitucionais, com as especificações feitas acima: a) tratados de direitos humanos internalizados com "quorum" qualificado (equivalentes às emendas constitucionais) são paradigma do controle concentrado (para além, obviamente, do controle "difuso"), cabendo, v.g., uma ADIn no STF a fim de invalidar norma infraconstitucional incompatível com eles; b) tratados de direitos humanos que têm apenas "status de norma constitucional" (não sendo equivalentes às emendas constitucionais, posto que não aprovados pela maioria qualificada do art. $5^{\circ}, \S 3^{\circ}$ ) são paradigma apenas do controle "difuso" de convencionalidade.

A jurista Flávia Piovesan, adotando essa mesma conduta, aduz que nos tratados de proteção aos direitos humanos ratificados anteriormente à Emenda Constitucional n. 45 de 2004 apenas não teriam passado pela formalidade exigida, ou seja, embora tenham ultrapassado o quorum de três quintos dos membros da Casa, não foram aprovados em dois turnos, sendo apenas em um torno de votação. Dessa forma, por força do parágrafo $2^{\circ}$ do art. $5^{\circ}$ da Carta Maior, defende que todos os tratados de Direitos Humanos, independentemente do "quorum" de sua aprovação, são materialmente constitucionais, compondo o bloco de constitucionalidade (PIOVESAN, Flávia. Temas de direitos humanos. 3. ed. São Paulo: Saraiva, 2009. p. 19-20). Sua tese é corroborada com quatro grandes argumentos: a) a interpretação sistemática da Constituição, de forma a dialogar os $\S \S 2^{\circ} \mathrm{e} 3^{\circ}$ do art. $5^{\circ}$, já que o último não revogou o primeiro, mas deve, ao revés, ser interpretado à luz do sistema constitucional; b) a lógica e racionalidade material que devem orientar a hermenêutica dos direitos humanos; c) a necessidade de evitar interpretações que apontem a agudos anacronismos da ordem jurídica; e d) a teoria geral da recepção do Direito brasileiro.

Dessa explicação se infere que enquanto os tratados versados sobre direitos humanos forem ratificados à luz da EC 45/2004, portanto, após o advento dessa emenda, serão eles materialmente e formalmente constitucionais, este último requisito devido à necessidade de se passar por crivo de um três quintos dos votos da Casa em dois turnos, já os tratados relativos aos direitos humanos aprovados anteriormente à emenda referida terão a natureza materialmente constitucional, pois não havia previsto o iter do parágrafo $3^{\circ}$ do artigo $5^{\circ}$ da Constituição Federal de 1988. 
da Convenção Americana de Direitos Humanos como sendo uma norma materialmente constitucional, mas não formalmente constitucional, uma vez que o parágrafo $3^{\circ}$ do artigo $5^{\circ}$ da Carta Magna incluiu procedimento a ser seguido para que um tratado ou convenção versando sobre de direitos humanos tenha força equivalente às emendas constitucionais.

Pois bem, a Execução Penal, em atendimento ao invocado nas Leis e Convenções em defesa dos direitos humanos, deixou claro, em seus artigos iniciais, seus objetivos, trazendo uma preocupação maior no efetivo cumprimento de sentença criminal ou decisão criminal e visou melhores condições para a harmônica integração social do condenado e do internado.

É o que se depreende do disposto no seu art. $1^{\circ}$, in verbis: A execução penal tem por objetivo efetivar as disposições de sentença ou decisão criminal e proporcionar condições para a harmônica integração social do condenado e do internado.

A finalidade da execução penal não é a retribuição, tampouco a prevenção. Constitui-se claramente na possibilidade de reintegrar socialmente o condenado, conforme, principalmente, à dignidade da pessoa humana e em respeito às necessidades básicas, essenciais de um indivíduo.

A individualização da pena é um exemplo da aplicação dos direitos humanos na Lei n. 7.210, veja-se o art. $5^{\circ}$ da Lei de Execuções Penais: Os condenados serão classificados, segundo os seus antecedentes e personalidade, para orientar a individualização da execução penal. Há aplicação da proporcionalidade da pena em que cada condenado tenha sua pena proporcionalmente de acordo com sua culpabilidade, personalidade, e fato cometido.

Assim sendo, a Lei de Execução Penal seguiu pontos essenciais da Declaração Universal de Direitos Humanos a fim de buscar um tratamento digno aos sentenciados e a Convenção Americana dos Direitos Humanos, como norma materialmente constitucional orienta o devido tratamento a qualquer pessoa de forma que sua violação é uma afronta direta a uma norma de grande força no ordenamento jurídico brasileiro sendo, portanto, um embate aos ditames legais de uma norma equivalente à constitucional. 


\section{A Execução Penal}

\subsection{Aspectos relevantes da Execução Penal}

7.1.1. Órgãos da execução e estabelecimentos penais (função de cada)

\subsubsection{Dos órgãos da execução}

A Lei de Execuções Penais, em seu artigo 61, elenca quais são os órgãos da execução penal, que, à luz do entendimento do jurista José Carlos Gobbis Pagliuca ${ }^{30}$, são entidades ou instituições que exercem, cada qual com suas funções, o sistema de funcionamento da execução penal. São entes autônomos e independentes, mas trabalham, muitas vezes em conjunto, para o mesmo fim.

Portanto, conforme aduz Mirabete, ${ }^{31}$ as atribuições pertinentes a cada um de tais órgãos foram estabelecidas de forma a evitar conflitos, realçando-se, ao contrário, a possibilidade de atuação conjunta, destinada a superar os inconvenientes graves resultantes do antigo e generalizado conceito de que a execução de penas e medidas de segurança é assunto de natureza meramente administrativa.

Logo, havendo maior divisão e independência dos órgãos, pretendeu-se dar maior eficiência e dinamização no processo executório concomitantemente com a união de forças para realização de um só objetivo. São os órgãos:

O Conselho Nacional de Política Criminal e Penitenciária, disposto no art. 62 da Lei de Execuções Penais, tem a sua sede na Capital da República e subordina-se ao Ministério da Justiça. Nos dizeres de Mirabete, ${ }^{32}$ é um órgão normativo e de fiscalização cabendo-lhe, ainda, contribuir, de modo direto e efetivo, para implementação das determinações e recomendações que fizer, com vistas na realização dos fins da reforma penal e penitenciária. Possui, por conseguinte, o escopo de contribuir como objetivo precípuo a elaboração, por parte do Governo, de um plano amplo e bem coordenado de controle do fenômeno da criminalidade.

Dessa forma, temos no art. 63 da Lei em estudo a composição do CNPCP e a duração do mandato de seus membros.

Já no art. 64, tem-se a competência no âmbito federal ou estadual do Conselho Nacional de Política Criminal Penitenciária, quais sejam: propor diretrizes da política criminal quanto à prevenção do delito, administração da Justiça Criminal

30 PAGLIUCA, José Carlos Gobbis. Direito penal, legislação especial e execução penal. 2. ed. São Paulo: Rideel, 2008. p. 216.

31 MIRABETE, Julio Fabbrini. Execução penal. 10. ed. São Paulo: Atlas, 2002. p. 161.

32 Id. Ibid., p. 162. 
e execução das penas e das medidas de segurança; contribuir na elaboração de planos nacionais de desenvolvimento, sugerindo as metas e prioridades da política criminal e penitenciária; promover a avaliação periódica do sistema criminal para a sua adequação às necessidades do País; estimular e promover a pesquisa criminológica; elaborar programa nacional penitenciário de formação e aperfeiçoamento do servidor; estabelecer regras sobre a arquitetura e construção de estabelecimentos penais e casas de albergados; estabelecer os critérios para a elaboração da estatística criminal; inspecionar e fiscalizar os estabelecimentos penais, bem assim informar-se, mediante relatórios do Conselho Penitenciário, requisições, visitas ou outros meios, acerca do desenvolvimento da execução penal nos Estados, Territórios e Distrito Federal, propondo às autoridades dela incumbida as medidas necessárias ao seu aprimoramento; representar ao Juiz da execução ou à autoridade administrativa para instauração de sindicância ou procedimento administrativo, em caso de violação das normas referentes à execução penal; representar à autoridade competente para a interdição, no todo ou em parte, de estabelecimento penal.

O Juízo da Execução: em tese, a pena deve ser executada na comarca onde o delito se consumou, tendo em vista a regra de competencia jurisdicional. Seria uma continuação do que dispõe o artigo 70 do Código de Processo Penal: A competência será, de regra, determinada pelo lugar em que se consumar a infração, ou, no caso de tentativa, pelo lugar em que for praticado o último ato de execução.

Porém, há casos em que o cumprimento da pena, em razão de interesse de segurança pública ou do próprio condenado, ocorre em local diverso da condenação, conforme explica Renato Marcão. ${ }^{33}$

Diversas são regras de fixação de competência que se pode catalogar. ${ }^{34}$ São elas: o Juízo da condenação em que mesmo havendo a transferência do condenado para comarca diversa, continua competente o Juízo da condenação para executar a pena; o Juízo onde estiver o estabelecimento cuja pena está sendo cumprida em que existindo a transferência do condenado do juízo da condenação para outra jurisdição, haverá reflexo na competência; Juízo onde se encontrar o processo de execução, regra esta que visa a celeridade na outorga da prestação jurisdicional, a economia processual e a decisões conflitantes; a fixação da competência se daria pelo estipulado em Lei (Estadual) de Organização Judiciária, portanto, nos entendimento do STF (HC 64.583, 2 a T., j.27-21987), A competência do juiz da execução é fixada pela lei local de organização judiciária,

33 MARCÃO, Renato. Lei de execução penal anotada e interpretada. 3. ed. Rio de Janeiro: Lumen Juris, 2009. p. 141 .

34 Apud. p. 143. 
isto é, pela lei do Estado onde a pena é cumprida, mesmo que a condenação tenha sido imposta em sede federal.

$\mathrm{O}$ art. 66 da LEP impôe ao magistrado as incumbências administrativas, judiciais e administrativo-judiciais que cumpre a ele decidir. São suas atribuições: aplicar aos casos julgados lei posterior que de qualquer modo favorecer o condenado; declarar extinta a punibilidade; decidir sobre: a) soma ou unificação de penas; b) progressão ou regressão nos regimes;c) detração e remição da pena;d) suspensão condicional da pena; e) livramento condicional; f) incidentes da execução; autorizar saídas temporárias; determinar: a) a forma de cumprimento da pena restritiva de direitos $e$ fiscalizar sua execução; b) a conversão da pena restritiva de direitos e de multa em privativa de liberdade;c) a conversão da pena privativa de liberdade em restritiva de direitos; d) a aplicação da medida de segurança, bem como a substituição da pena por medida de segurança; e) a revogação da medida de segurança; f) a desinternação e o restabelecimento da situação anterior; g) o cumprimento de pena ou medida de segurança em outra comarca; $h$ ) a remoção do condenado na hipótese prevista no $\S 1^{\circ}$ do artigo 86 , desta Le; zelar pelo correto cumprimento da pena e da medida de segurança; inspecionar, mensalmente, os estabelecimentos penais, tomando providências para o adequado funcionamento e promovendo, quando for o caso, a apuração de responsabilidade; interditar, no todo ou em parte, estabelecimento penal que estiver funcionando em condições inadequadas ou com infringência aos dispositivos desta Lei; compor e instalar o Conselho da Comunidade; e emitir anualmente atestado de pena a cumprir.

$\boldsymbol{O}$ Ministério Público: tem como função institucional delimitada pela Constituição Federal zelar pelo efetivo respeito dos Poderes Públicos e dos serviços de relevância pública aos direitos assegurados nesta Constituição, promovendo as medidas necessárias a sua garantia (art. 129, II CF). Assim, nada mais correto o papel desempenhado por esse órgão no que dispõe o art. 67 da Lei n. 7.210 de 1984: O Ministério Público fiscalizará a execução da pena e da medida de segurança, oficiando no processo executivo e nos incidentes da execução.

Entende Renato Marcão ${ }^{35}$ que a não observância do disposto no artigo mencionado, acarreta nulidade, de modo que o Ministério Público deve intervir no processo de execução, fiscalizando e postulando, quando necessário, o que for de direito, independentemente da natureza da pena ou da medida de segurança que estiver sendo executada. No art. 68 da Lei de Execuções Penais, por sua vez, tem-se outros ofícios reservados ao Ministério Público.

35 MARCÃO, Renato. Lei de execução penal anotada e interpretada. 3. ed. Rio de Janeiro: Lumen Juris, 2009. p. 173. 
O Conselho Penitenciário: $a$ função desse órgão é consultiva e fiscalizadora, é de certa forma um elo entre o Poder Executivo e o Judiciário. Cada membro do Conselho tem um mandato de quatro anos (art. 69 da LEP)

Além disso, o Conselho Penitenciário tem a incumbência de emitir parecer sobre indulto e comutação de pena, excetuada a hipótese de pedido de indulto com base no estado de saúde do preso; inspecionar os estabelecimentos e serviços penais;apresentar, no $1^{\circ}$ (primeiro) trimestre de cada ano, ao Conselho Nacional de Politica Criminal e Penitenciária, relatório dos trabalhos efetuados no exercício anterior; e supervisionar os patronatos, bem como a assistência aos egressos.

Os Departamentos Penitenciários, divido em Departamento Penitenciário Nacional e Departamento Penitenciário Local. Aquele é subordinado ao Ministério da Justiça e é o órgão executivo da Política Penitenciária Nacional de apoio administrativo e financeiro do Conselho Nacional de Política Criminal e Penitenciária.

Possui as seguintes atribuições: acompanhar a fiel aplicação das normas de execução penal em todo o Território Nacional; inspecionar e fiscalizar periodicamente os estabelecimentos e serviços penais; assistir tecnicamente as Unidades Federativas na implementação dos princípios e regras estabelecidos nesta Lei; colaborar com as Unidades Federativas mediante convênios, na implantação de estabelecimentos e serviços penais; colaborar com as Unidades Federativas para a realização de cursos de formação de pessoal penitenciário e de ensino profissionalizante do condenado e do internado; estabelecer, mediante convênios com as unidades federativas, o cadastro nacional das vagas existentes em estabelecimentos locais destinadas ao cumprimento de penas privativas de liberdade aplicadas pela justiça de outra unidade federativa, em especial para presos sujeitos a regime disciplinar; e a coordenação e supervisão dos estabelecimentos penais e de internamento federais.

E o Departamento Penitenciário Local, ou órgão similar, por sua vez, tem por finalidade supervisionar e coordenar os estabelecimentos penais da Unidade da Federação a que pertencer, conforme o artigo 74 da Lei em estudo.

O Patronato: são instituições públicas ou particulares que servem a prestar assistência aos albergados e egressos do sistema penitenciário. Ainda incumbe-lhes orientar os condenados à pena restritiva de direitos, fiscalizar o cumprimento das penas de prestação de serviços à comunidade e de limitação de fins de semana e colaborar na fiscalização do cumprimento do sursis e do livramento da condicional, conforme se pode aduzir dos art. 78 e 79 da Lei n. 7.210/84.

Cumpre salientar que a fiscalização do cumprimento pela esposa do condenado, nos ensinamentos de Renato Marcão, ${ }^{36}$ não é possível.

36 MARCÃO, Renato. Lei de Execução Penal anotada e interpretada. 3. ed. Rio de Janeiro: Lumen Juris, 2009. 
O Conselho da Comunidade: visou-se com o intuito de enfrentar os problemas referentes ao delito, ao delinqüente e à pena o apoio comunitário que passaria a fiscalizar tanto as reações penais em meio fechado como nas penas privativas de liberdade e medida de segurança como em meio aberto como as penas de multa e restritiva de direitos.

Buscou-se, igualmente, uma melhor adaptação e reinserção do antigo recluso à sociedade. Dessa forma, atribuíram ao Conselho as seguintes funções: visitar, pelo menos mensalmente, os estabelecimentos penais existentes na comarca; entrevistar presos; apresentar relatórios mensais ao Juiz da execução e ao Conselho Penitenciário; $e$ diligenciar a obtenção de recursos materiais e humanos para melhor assistência ao preso ou internado, em harmonia com a direção do estabelecimento. (art. 81)

\subsubsection{Dos estabelecimentos penais}

Os estabelecimentos penais estão dispostos na Lei n. $7.210 / 84$ (arts. 82 a 104), quais sejam: a penitenciária, a colônia agrícola, industrial ou similar, a cada do albergado, o centro de observação, o hospital de custódia e tratamento psiquiátrico, e, por fim, a cadeia pública.

No art. 82 da mesma Lei temos a obediência à Carta Magna em seu art. $5^{\circ}$, inciso XLVIII, que dispõe: a pena será cumprida em estabelecimentos distintos, de acordo com a natureza do delito, a idade e o sexo do apenado.

Sujeição esta que no parágrafo $1^{\circ}$ do art. 82 tem-se o condenado maior de 60 anos o recolhimento em estabelecimento próprio e adequado à sua condição pessoal e no parágrafo $2^{\circ}$ a possibilidade de num mesmo local, desde que havendo separação com destinação diversa, o abrigo de diversos tipos de condenados.

Há a permissão do aleitamento materno para as condenadas em respeito à dignidade da pessoa humana e aos direitos e garantias fundamentais.

São os estabelecimentos penais:

A Penitenciária teria a destinação ao condenado à pena de reclusão, em regime fechado, nos termos do artigo 87 da Lei de Execuções Penais. Com advento da Lei 11.671/08, houve a disposição acerca da transferência e inclusão de presos em estabelecimentos penais federais de segurança máxima.

A cela prisional possuirá, em tese, as condições mínimas de higiene e salubridade como dormitório, aparelho sanitário e lavatório. Haverá, em relação às condenadas, uma seção para as gestantes, para a parturiente e para a creche. E

p. 189. 
penitenciária dos homens será construída em local distante do centro urbano, mas não a ponto de impedir a visitação.

A Colônia Agrícola, a Industrial ou a Similar destinase ao cumprimento da pena em regime semi-aberto. Na falta de vaga nesse tipo de estabelecimento, discute-se a possibilidade de cumprimento em um regime mais rigoroso, não seria possível à luz de parte da doutrina pelo fato de se tratar um constrangimento ilegal ao condenado, sendo passível de habeas corpus; de outro lado, temos a possibilidade pela inexistência da casa de albergado a prisão domiciliar.

A Casa de Albergado se destina ao cumprimento de pena privativa de liberdade, em regime aberto, e da pena de limitação de fim de semana.

Nos termos do art. 33, parágrafo $1^{\circ}$, alínea "c", do Código Penal, considerase regime aberto a execução da pena em casa de albergado ou estabelecimento adequado. Porém, as Casas de Albergados, segundo Janaina Conceição Paschoal ${ }^{37}$ em razão de o regime criado para ter lugar nas Casas de Albergado não ter se concretizado, uma Comissão de juristas, presidida por Miguel Reale Júnior, propôs a extinção desse tipo de regime de cumprimento de pena.

$\boldsymbol{O}$ Centro de Observação, local em que se realizarão os exames gerais e o criminológico, cujos resultados serão encaminhados à Comissão Técnica de Classificação. Nesse estabelecimento, poderão ser realizadas pesquisas criminológicas, e ainda, poderá fornecer informações úteis para classificação dos condenados e a efetiva individualização da pena.

O Hospital de Custódia e Tratamento Psiquiátrico se destina aos inimputáveis e semi-imputáveis referidos no artigo 26 e seu parágrafo único do Código Penal. Determina o artigo 26 do Código Penal: Inimputáveis É isento de pena o agente que, por doença mental ou desenvolvimento mental incompleto ou retardado, era, ao tempo da ação ou da omissão, inteiramente incapaz de entender o caráter ilícito do fato ou de determinar-se de acordo com esse entendimento. Trata-se da Medida de Segurança a ser imposta a esses inimputáveis e semi-imputáveis.

A Cadeia Pública se destina ao recolhimento de presos provisórios e não aos definitivamente condenados. É de extrema utilidade tal diferenciação para que a prisão provisória haja como custódia daquele a quem se imputa a prática do crime a fim de que fique à disposição da autoridade judicial durante o inquérito ou a ação penal e não para o cumprimento da pena, que não foi imposta ou que não é definitiva.

37 PASCHOAL, Janaina Conceição. Direito penal: parte geral. São Paulo: Manole, 2003. p. 117. 
7.1.2. Principais direitos e deveres dos condenados e presos provisórios

O art. 39 da Lei de Execuções Penais especifica os deveres do condenado, conforme podemos explicitá-los: comportamento disciplinado e cumprimento fiel da sentença; obediência ao servidor e respeito a qualquer pessoa com quem deva relacionarse; urbanidade e respeito no trato com os demais condenados; conduta oposta aos movimentos individuais ou coletivos de fuga ou de subversão à ordem ou à disciplina; execução do trabalho, das tarefas e das ordens recebidas; submissão à sanção disciplinar imposta; indenização à vitima ou aos seus sucessores; indenização ao Estado, quando possivel, das despesas realizadas com a sua manutenção, mediante desconto proporcional da remuneração do trabalho; higiene pessoal e asseio da cela ou alojamento; conservação dos objetos de uso pessoal. São os mesmos deveres a serem aplicados aos presos provisoriamente.

Dessa forma, para que seja possível a permanência do condenado e a execução penal cumpra com seu objetivo de efetivar as disposições da sentença ou decisão criminal, e para a harmonia na integração do condenado e do internado à sociedade, é necessário o devido cumprimento dos deveres dispostos nos incisos do artigo mencionado.

Todavia, não só estão elencados os deveres do condenado, como também os direitos os quais ele pode invocar para o cumprimento de sua pena ou medida de segurança de maneira a manter sua integridade física e moral, ou seja, a dignidade da pessoa humana.

Para isso, a Lei n. 8.210/84 dispôs em seus art. 40 a 43 os direitos a eles conferidos. A Convenção Americana de Direitos Humanos em seu art. $5^{\circ}$, itens 1 e 2 , corroboram tais direitos quando impõem:

Artigo $5^{\circ}$ - Direito à integridade pessoal

1. Toda pessoa tem direito a que se respeite sua integridade física, psíquica e moral.

2. Ninguém deve ser submetido a torturas, nem a penas ou tratos cruéis, desumanos ou degradantes. Toda pessoa privada de liberdade deve ser tratada com o respeito devido à dignidade inerente ao ser humano.

Segundo Luiz Flávio Gomes, ${ }^{38}$ o respeito à integridade física, psíquica e moral nada mais significa que a expressão da dignidade da pessoa humana defendida pela Carta Magna em seu art. $1^{\circ}$, inciso III. Ademais, quanto às torturas, ninguém deve ser submetido a elas, nem às penas de trato cruéis, desumanos e degradantes, assim toda pessoa privada de sua liberdade tem o direito de ser tratada em respeito à dignidade

38 GOMES, Luís Flávio; MAZZUOLI, Valério de Oliveira. Comentários à Convenção Americana sobre Direitos Humanos. Pacto de San José da Costa Rica. 2. ed. São Paulo: Revista dos Tribunais, 2009. v. 4, p. $39-40$. 
inerente ao ser humano, o mesmo se defende na Constituição Federal como podemos aduzir pelo art. $5^{\circ}$ : inciso XLVII e XLIX.

São direitos do preso o disposto no art. 41 da Lei de Execuções Penais, de acordo com o seguinte aduzido: alimentação suficiente e vestuário; atribuição de trabalho e sua remuneração;Previdência Social; constituição de pecúlio; proporcionalidade na distribuição do tempo para o trabalho, o descanso e a recreação; exercício das atividades profissionais, intelectuais, artísticas e desportivas anteriores, desde que compativeis com a execução da pena; assistência material, à saúde, jurídica, educacional, social e religiosa;proteção contra qualquer forma de sensacionalismo; entrevista pessoal $e$ reservada com o advogado; visita do cônjuge, da companheira, de parentes e amigos em dias determinados; chamamento nominal; igualdade de tratamento salvo quanto às exigências da individualização da pena; audiência especial com o diretor do estabelecimento; representação e petição a qualquer autoridade, em defesa de direito; contato com o mundo exterior por meio de correspondência escrita, da leitura e de outros meios de informação que não comprometam a moral e os bons costumes; atestado de pena a cumprir, emitido anualmente, sob pena da responsabilidade da autoridade judiciária competente.

Demonstra o artigo condições mínimas que os presos deverão ter para o convívio adequado no cumprimento de sua pena. O mesmo se faz para garantir a integridade do condenado nos artigos 42 e 43 da referida LEP.

Enfim, a humanidade da pena determina que o homem não pode ser tratado como meio mas como fim, como pessoa, o que impõe limitação a quantidade e à qualidade da pena e, consequentemente, o respeito à vida e a proibição de penas cruéis ou degradantes, incluído o rigor desnecessário e as privações indevidas impostas aos condenados.

\subsubsection{Guia de recolhimento e sua relação com os requisitos}

A Lei de Execuções Penais traz em seu art. $106^{39}$ os requisitos que deverão conter na guia de recolhimento, que será entregue à autoridade administrativa seguindo as formalidades abrangidas no artigo. Veja-se: o nome do condenado; a sua qualificação civil e o número do registro geral no órgão oficial de identificação; o inteiro teor da denúncia $e$ da sentença condenatória, bem como certidão do trânsito em julgado; a informação

39 O artigo mencionado substitui a regra anterior que era a adoção do artigo 676 do Código de Processo Penal, que expunha o seguinte: A carta de guia, extraida pelo escrivão e assinada pelo juiz, que a rubricará em todas as folhas, será remetida ao diretor do estabelecimento em que tenha de ser cumprida a sentença condenatória, e conterá: I - o nome do réu e a alcunha por que for conhecido; Il a sua qualificação civil (naturalidade, filiação, idade, estado, profissão), instrução e, se constar, número do registro geral do Instituto de Identificação e Estatística ou de repartição congênere; III - o teor integral da sentença condenatória e a data da terminação da pena. 
sobre os antecedentes e o grau de instrução; a data da terminação da pena; outras peças do processo reputadas indispensáveis ao adequado tratamento penitenciário.

A guia de recolhimento tem os requisitos necessários para a própria efetivação da individualização da pena, pois identificando o condenado, mencionando a causa de sua pena com a explicitação do conteúdo da denúncia e da sentença condenatória, bem como informações atinentes aos antecedentes e grau de instrução, até a data de fim da pena e outras peças do processo reputadas indispensáveis ao adequado tratamento penitenciário. Tem-se o objetivo não só de efetivar as disposições da sentença ou decisão criminal, como também a tentar proporcionar condições para a harmônica integração social do condenado e do internado, invocado no art. $1^{\circ}$ da Lei n. 7.210/84. É o devido cumprimento do disposto como direito e garantia fundamental na Carta Magna em seu artigo $5^{\circ}$, incisos XLV e XLVI.

O ilustre Julio Fabbrini Mirabete ${ }^{40}$ afirma que pelo contido no inciso IV do artigo 106, fica fixado no instrumento [guia de recolhimento] tudo de importância para a individualização da execução e se fornecem os elementos indispensáveis para os exames de personalidade e, principalmente, criminológico.

E ainda, como instrumento do título executório que é, indica à administração penal qual a pena a ser executada, qual a sua duração e em que regime deve ser posto inicialmente o condenado, fornecendo também, os elementos indispensáveis para o tratamento penitenciário.

Isso somente corrobora a importância da guia como forma de individualização da pena com o fito de execução da pena.

\subsubsection{Da execução provisória e a possibilidade da guia provisória}

Existe uma discussão de grande relevância acerca da necessidade de expedição da guia para início da execução da pena. Pois bem, há uma corrente pendente para o lado em respeito ao formalismo jurídico disposto no art. 105 da Lei de Execuções Penais in verbis:

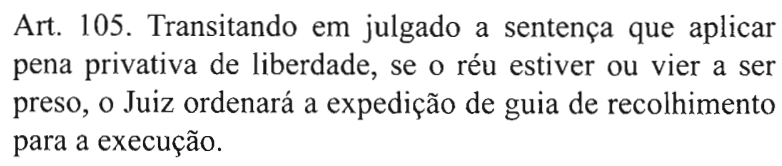

Dessa forma, depreende-se do transcrito que a guia de recolhimento somente será expedida após o trânsito em julgado da sentença impossibilitando, portanto, qualquer tipo de execução provisória da pena.

40 MIRABETE, Julio Fabbrini. Execução penal. São Paulo: Atlas, 2002. p. 294. 
Não falta jurisprudência a favor desse formalismo do artigo como se pode perceber em trechos colhidos pelo professor Renato Marcão: ${ }^{41}$
A teor do disposto no art. 105 da Lei 7.210/84, o processo de execução somente poderá ser instaurado, pelo juízo competente, após o recolhimento do condenado.(RT 844/528)
Somente com a expedição da guia de recolhimento, após o transito em julgado da condenação, é que a sentença ganha força executiva e deve ser providenciado o início do cumprimento da pena no regime estabelecido na decisão. (RJDTACrimSP 40/298)
$\mathrm{O}$ art. 105 da LEP, ao tratar das execuções penais privativas de liberdade, dispõe que sem a condenação definitiva não se expede a guia de recolhimento, e sem a guia não se inicia a execução, e uma vez não iniciada a formal execução, não será, também, admissível a progressão do regime prisional do fechado para o semi-aberto. (RT744/595)

Todavia, em outro diapasão, há o entendimento de que seria possível a execução provisória do acusado. Pode-se agasalhar com tal opinião baseando-se no disposto no parágrafo único do art. $2^{\circ}$ da Lei de Execuções Penais que dita: Esta Lei aplicar-se-á igualmente ao preso provisório e ao condenado pela Justiça Eleitoral ou Militar, quando recolhido a estabelecimento sujeito à jurisdição ordinária.

Nesse sentido, pode-se interpretar que nada impede a possibilidade de uma execução provisória da sentença e é o que se defende pelos ensinamentos de José Carlos Gobbis Pagliuca ${ }^{42}$ com fulcro no Provimento 653/99 do Conselho Superior da Magistratura do Estado de São Paulo, cujo art. $2^{\circ}$ da Lei n. 7.210 é usado como analogia e conclui-se no art. $1^{\circ}$ do Provimento que: A guia de recolhimento provisória será expedida quando do recebimento de recurso da sentença condenatória, desde que o condenado esteja preso em decorrência de prisão processual, devendo ser remetido ao Juizo de Execução Criminal. Ademais, tal assertiva, além de estabelecer a possibilidade da extração e cumprimento de guia provisória, não define se ela se dá com ou sem recurso da acusação.

O Conselho Nacional de Justiça também se manifestou acerca do assunto permitindo, na Resolução 19/06 e posteriormente com sua redação alterada com a Resolução 57, a guia de recolhimento provisório que no art. $1^{\circ}$ ficou definido o seguinte:

Art. $1^{\circ}$ A guia de recolhimento provisório será expedida quando da prolação da sentença ou acórdão condenatório, ressalvada a hipótese de possibilidade de interposição

\footnotetext{
41 MARCÃO, Renato. Lei de execução penal anotada e interpretada. 3. ed. Rio de Janeiro: Lumen Juris, 2009. p. 234.

42 PAGLIUCA, José Carlos Gobbis. Direito penal, legislação especial e execução penal. 2. ed. São Paulo: Rideel, 2008. p. 230.
} 
de recurso com efeito suspensivo por parte do Ministério Público, devendo ser prontamente remetida ao Juízo da Execução Criminal.

O Supremo Tribunal Federal já havia sedimentado de que os benefícios da execução poderiam ser aplicados ao preso cuja condenação ainda não havia transitado em julgado. Dessa forma, apresentou duas Súmulas, quais sejam:

Súmula 716, STF: Admite-se a progressão de regime de cumprimento da pena ou a aplicação imediata de regime menos severo nela determinada, antes do trânsito em julgado da sentença condenatória.

Súmula 717, STF: Não impede a progressão de regime de execução da pena, fixada em sentença não transitada em julgado, o fato de o réu se encontrar em prisão especial

Os julgados a favor desse consenso são diversos como podemos depreender:

A execução provisória da pena privativa de liberdade, antes do trânsito em julgado da decisão condenatória, não constitui violação à norma constitucional (STF, HC 72.077/3-RS, $2^{\mathrm{a}}$ T., rel. Min. Maurício Corrêa, j. 3-3-1995, DJU, 16 jun. 1995, RT726/561).

Transitado em julgado para a acusação, e tendo o sentenciado cumprido mais de $1 / 6$ da pena, assiste-lhe direito à obtenção de guia de recolhimento para requerer a progressão de regime prisional (STJ, REsp. 59.355/0, $5^{\text {a }}$ T., rel. Min. Cid Flaquer Scartezzini, j. 9-9-1997).

Contudo, é motivo de controvérsia o caso da guia de recolhimento provisória poder ser expedida antes ou somente depois do trânsito em julgado para o Ministério Público. O entendimento jurisprudencial é discutível, pois temos ambos os lados em divergência acirrada, veja-se:

A corrente contra a possibilidade de uma execução provisória quando não estiver transitado em julgado recurso para o Ministério Público:

HABEAS CORPUS. PENAL. EXECUÇÃO PROVISÓRIA DA SENTENÇA CONDENATÓRIA. REGIME SEMIABERTO. PENDÊNCIA DE RECURSO DA ACUSAÇÃO. IMPOSSIBILIDADE.

1. Inexistindo o trânsito em julgado para o órgão acusador, já que se encontra pendente recurso que objetiva o aumento da pena e, por conseguinte, o agravamento do regime prisional, inexiste constrangimento ilegal, pois cuida-se, ainda, de prisão provisória, não havendo que se falar em execução antecipada da pena; 2 . Ordem denegada, com recomendação. (STJ: HC 43116/MG, Rel. Min. Hélio Quaglia Barbosa, DЛ 06/02/2006, p. 353) 
PROCESSO PENAL. SENTENÇA CONDENATÓRIA. EXECUÇÃO PROVISÓRIA.» 1. Sem o trânsito em julgado da decisão condenatória para o Ministério Público, não há que falar em execução provisória. Código de Processo Penal, artigo 597.2. Recurso ordinário improvido." ( $6^{\mathrm{a}}$ Turma V.U. ROHC n ${ }^{\circ} 8.593$ de São Paulo -Rei. Min. Hamilton Carvalhido - j. em 01.07 .99 - D.J.U. de 02.08 .99 - pág. 224). CONFLITO NEGATIVO DE COMPETENCIA EXECUÇÃO PROVISÓRIA DA PENA - POSSIBILIDADE SÚMULA No 716 DO STF RESOLUÇÃO No 19 DO CNJ - COMPETÊNCIA DO JUIZZO SUSCITADO VOTO VENCIDO. A execução provisória da pena é possível quando a sentença transitou em julgado para o Ministério Público, pendente apenas de recurso defensivo, conforme entendimento jurisprudencial dominante, reforçado pela Súmula n 716 do STF. V.V. " "'Cabe ao Juiz que conheceu do processo criminal e condenou o réu, dirimir questões atinentes à execução provisória da pena segundo as regras da execução penal. Não há regulamentação específica, estabelecendo a competência do juízo da execução penal para essa espécie de procedimento antes de transitada em julgado a sentença condenatória para a defesa (Desembargador Júlio Cezar Guttierrez)"', (TJMG, Autos n. ${ }^{\circ} 1.0000 .08 .485706-$ 9/000, rel. WALTER PINTO DA ROCHA, j. em 28-012009)

EXECUÇÃO PROVISÓRIA IMPOSSIBILIDADE. Somente admite-se a execução provisória quando a sentença condenatória tenha transitado em julgado para o órgão acusatório ou se houver recurso exclusivo da defesa. (TJSP, Ag. em Ex. Penal n 990.08.106317-4, 14 ${ }^{\text {a }}$ Câm. rel. Wilson Barreira, V.U, j. em 18-12-2008)

É impossível a expedição de carta de guia provisória ao condenado de regime semi-aberto quando pendente recurso ministerial objetivando a determinação da modalidade fechada, pois seria impróprio afirmar que o sentenciado tenha direito consolidado ao cumprimento da pena sob o regime intermediário (RJDTACrimSP 61/163).

A Corrente a favor:

Apreciação do pedido de progressão de regime prisional, independentemente do trânsito em julgado da sentença condenatória. Cabimento, já que o Provimento n. 653/99 do Conselho Superior da Magistratura, e a Súmula n. 716 do STF, nã fazem qualquer menção ou restrição a respeito de recurso do Ministério Público. Ordem parcialmente concedida, para que seja analisado o pedido de progressão de regime prisional em favor do paciente (TJSP, HC 1.137.566.3/0, 7a. CCrim, rel. Des. J. Martins, j. 29-112007) 


\begin{abstract}
RECURSO ORDINÁRIO EM HABEAS CORPUS. PROCESSUAL PENAL. PENA: EXECUÇÃO PROVISÓRIA. PROGRESSÃO DE REGIME ANTES DO TRÂNSITO EM JULGADO DA CONDENAÇÃO: POSSIBILIDADE. PRECEDENTES. RESOLUÇÃO N. 19, DE 29 DE AGOSTO DE 2006, DO CONSELHO NACIONAL DE JUSTIÇA. RECURSO CONHECIDO E PROVIDO. 1. A jurisprudência deste Supremo Tribunal não exige o trânsito em julgado da condenação para que seja possível a progressão de regime. Precedentes. $2 . \mathrm{O}$ art. $1^{\circ} \mathrm{da}$ Resolução n. 19 do Conselho Nacional de Justiça estabelece que a guia de recolhimento provisório seja expedida após a prolação da sentença ou do acórdão condenatório, ainda sujeito a recurso sem efeito suspensivo, devendo ser prontamente remetida ao Juízo da Execução Criminal. 3. Recurso conhecido e provido.
\end{abstract}

$[\ldots]$

Em 9 de agosto de 2006, ao analisar a liminar requerida nos autos da Reclamação n. 4456, entendera o eminente Ministro Sepúveda Pertence que a "invocação da ausência de trânsito em julgado da condenação para a não-expedição da guia de recolhimento provisória implica o descumprimento da decisão proferida no HC 87.801. Sua excelência deferiu então a liminar, a fim de que a Autoridade reclamada determinasse "a imediata expedição da Guia de Recolhimento Provisório, independentemente de eventual trânsito em julgado da condenação imposta ao Reclamante" (STF, RHC 92872 I MG, Rel. Min. CÁRMEN LÚCIA, $1^{\mathrm{a}}$ T., D.J 15.02.08).

PROCESSUAL PENAL. HABEAS CORPUS. FURTO QUALIFICADO E ROUBO MAJORADO. RÉU QUE PERMANECEU CUSTODIADO AO LONGO DO PROCESSO. APELAÇ̃̃O DO MINISTÉRIO PÚBLICO. POSSIBILIDADE DE PROGRESSÃO DE REGIME ANTES DO TRÂNSITO EM JULGADO DA SENTENÇA CONDENATÓRIA.

I A pendência de julgamento do recurso de apelação interposto pelo Ministério Público não obsta a formação do Processo de Execução Criminal provisória. (Precedentes).

II "Admite-se a progressão de regime de cumprimento da pena ou a aplicação imediata de regime menos severo nela determinada, antes do trânsito em julgado da sentença condenatória." (Súmula n 716 do c. Pretório Excelso). Ordem concedida. (STJ, HC 93795/SP, Rel. Ministro FELIX FISCHER, QUINTA TURMA, julgado em 26/02/2008, DJe 07/04/2008.)

PROCESSUAL PENAL. HABEAS CORPUS. PROGRESSÃO DE REGIME. LIBERDADE CONDICIONAL. BENEFÍCIOS DECORRRENTES 
DA EXECUÇÃO DA PENA. COMPETÊNCIA PARA APRECIAÇÃO ATRIBUÍDA AO JUIZZO DA EXECUÇÃO. GULA DE RECOLHIMENTO PROVISÓRIO. EXECUÇÃO PROVISÓRIA DA REPRIMENDA SEM TRÂNSITO EM JULGDO DA CONDENAÇÃO PARA A ACUSAÇÃO. POSSIBILIDADE. SÚMULA 716 DO STF.

1. Tanto a progressão de regime como a liberdade condicional são benefícios decorrentes do cumprimento da pena e, portanto, sujeitos à deliberação primeira do juízo da execução.

2. Considerando recente precedente da Suprema Corte (HC $87.801 / \mathrm{SP}$ ), bem assim os princípios informadores do direito penal - não-culpabilidade e interpretação mais favorável ao réu -, a partir da sentença condenatória, havendo ou não recurso da acusação, tem o réu o direito à expedição da guia de execução provisória, para que possa, desde então, exercer os direitos decorrentes da execução da reprimenda. Permanece intacta, vale destacar, a Súmula 716, do Supremo Tribunal Federal, ao consignar que "admite-se a progressão de regime de cumprimento da pena ou a aplicação imediata de regime menos severo nela determinada, antes do trânsito em julgado da sentença condenatória." Antes do trânsito em julgado da sentença condenatória quer significar na pendência de recurso com efeito suspensivo, seja da defesa, seja da acusação.

3. Para que a expedição da guia de recolhimento provisório tenha aptidão para produzir os efeitos pretendidos pela impetrante possibilidade de obtenção de progressão de regime ou liberdade condicional -, urge reconhecer, como já o fez o Supremo Tribunal Federal, a inconstitucionalidade do $\S 1^{\circ}$ do art. $2^{\circ}$ da Lei $n^{\circ} 8.072 / 1990$, na linha dos precedentes desta $3^{a}$ Turma.

4. Concessão parcial da ordem de habeas corpus para a expedição de guia de execução provisória da pena e para o afastamento do óbice legal à progressão de regime de cumprimento de pena constante do $\S 1^{\circ}$ do art. $2^{\circ}$ da Lei $n^{\circ}$ 8.072/1990. (TRF $1^{\text {a }}$ Região, HC - 200601000468914/MT, $3^{\mathrm{a}} \mathrm{T}$., rel. JUIZ FEDERAL SAULO CASALI BAHLA, D.J 02/03/07)

Assim sendo, nada mais sensato, diante da delonga processual para o trâmite definitivo de um processo desde seu início até sua sentença, que haja a possibilidade de expedição de uma guia de recolhimento provisória, bem como a respectiva execução provisória da pena antes do trânsito em julgado para o Ministério Público.

É respeitar, antes de tudo, um dos princípios fundamentais elencados no artigo $1^{\circ}$, inciso III da Carta Magna, a dignidade da pessoa humana, bem como aos direitos 
humanos positivados sob a forma de direitos e garantias fundamentais relacionados no art. $5^{\circ}$ da mesma Lei Máxima.

7.1.5. Das penas restritivas de direito, da multa e do livramento da condicional

7.1.5.1. Das penas restritivas de direito e da pena de multa

As penas restritivas de direito e a multa contidas no Código Penal são espécies de penalidades já invocadas pela Carta Magna em seu art. $5^{\circ}$, inciso XLVI, cujo objetivo precípuo era individualizar a pena, sob a forma de lei específica, e definir o seu procedimento.

Reza o art. $5^{\circ}$, inciso XLVI da Constituição Federal que a lei regulará a individualização da pena e adotará, entre outras, as seguintes: privação ou restrição da liberdade; perda de bens; multa; prestação social alternativa; suspensão ou interdição de direitos.

As penas elencadas são condizentes com o princípio da individualização das penas que, à luz das palavras do professor Alexandre de Moraes, ${ }^{43}$ o princípio da individualização da pena exige uma estreita correspondência entre a responsabilização da conduta do agente e a sanção a ser aplicada, de maneira que a pena atinja suas finalidades de prevenção e repressão. Assim, a imposição da pena depende do juízo individualizado da culpabilidade do agente.

O Código Penal, por sua vez, em cumprimento com o disposto pela Lei Maior, no artigo 43 especificou como penas restritivas de direito as seguintes espécies: prestação pecuniária; perda de bens e valores; prestação de serviço à comunidade ou a entidades públicas; interdição temporária de direitos; e limitação de fim de semana.

A pena de prestação pecuniária tem por escopo de ser paga à vítima ou à instituição de finalidade social, pública ou não.

A perda de bens e valores ocorrerá em favor do Fundo Penitenciário Nacional, tendo a condição de não exceder ao montante do prejuízo causado, ou o provento auferido pelo condenado ou por terceiro, em decorrência da prática do crime. Não se confunde aqui com o perdimento de bens previsto no art. 91, II, "b" do Código Penal, pois, nesse caso, tem-se um efeito da condenação, isto é, o condenado perde não só os bens produto do crime, como também sofre a pena.

A prestação do serviço à comunidade refere-se somente às penas privativas de liberdade superiores a 6 meses que podem ser substituídas por essa modalidade em que os serviços são prestados em escolas, entidades assistenciais, hospitais etc.

$\overline{43}$ MORAES, Alexandre de. Direitos humanos fundamentais: teoria geral. 8. ed. São Paulo: Atlas, 2007. p. 240. 
A interdição temporária de direitos está elencada no art. 47 e seus incisos, quais sejam: proibição do exercício de cargo, função ou atividade pública, bem como de mandato eletivo; proibição do exercicio de profissão, atividade ou oficio que dependam de habilitação especial, de licença ou autorização do poder público; suspensão de autorização ou de habilitação para dirigir veículo; proibição de freqüentar determinados lugares.

E a limitação de fim de semana que, conforme prevê o art. 48 do Código Penal, é o caso da permanência do condenado, aos sábados e domingos, durante 5 horas em casa de albergado ou outro estabelecimento adequado, e nesse período, poderão ser ministrados cursos, palestras ou atividades educativas. Depreende-se dessa espécie de pena restritiva de direito como sendo praticamente inaplicável, vez que não se tem as referidas Casas de Albergado e o Estado não dispõe de atividades educativas voltadas aos condenados nos fim de semanas.

O Lei Penal definiu a pena de multa como sendo: o pagamento ao fundo penitenciário da quantia fixada na sentença e calculada em dias-multa. Será, no mínimo, de 10 (dez) e, no máximo, de 360 (trezentos e sessenta) dias-multa, em seu artigo 49.

Pois bem, a pena de multa, por sua vez, nos ensinamentos da professora Janaina Conceição Paschoal, ${ }^{44}$ pode ser cominada como pena principal isolada ou cumulativamente, também pode ser substituída com a pena privativa de liberdade, sendo que a condição para que isso possa ocorrer está disposto no parágrafo segundo do artigo 44, cuja redação nos remete a uma condenação igual ou inferior a um ano de uma pena privativa de liberdade e as penas privativas de liberdade superiores a um ano, podem ser substituídas por duas restritivas ou uma restritiva e uma multa.

O critério adotado para se mensurar o quantum da multa é o cálculo em dias-multa, sendo no mínimo 10 dias-multa e máximo 360 dias-multa, que será fixado pelo magistrado dentro dos limítrofes não inferior a 1/30 do salário mínimo a 5 salários mínimos.

Até 1996, na antiga redação do art. 51 do Código Penal, a multa não paga ou quando o solvente frustrasse a execução, era convertida em pena de detenção, logo convertida e pena privativa de liberdade. Discutiu-se muito acerca dessa antiga redação, pois dessa forma, entendia-se a possibilidade de prisão por dívida, o que, no disposto na Carta Magna, era vedado.

É o que se aduz pelo disposto no art. $5^{\circ}$ : inciso LXVII, primeira parte:

LXVII - não haverá prisão civil por dívida, salvo a do responsável pelo inadimplemento voluntário e inescusável

44 PASCHOAL, Janaina Conceição. Direito penal: parte geral. São Paulo: Manole, 2003. p. 131-134. 
de obrigação alimentícia e a do depositário infiel; (grifos à parte)

Assim, com a edição da Lei n. 9.268 de 1996, a redação do art. 51 do Código Penal foi alterada para:

Art. 51 Transitada em julgado a sentença condenatória, a multa será considerada dívida de valor, aplicando-se-lhes as normas da legislação relativa à dívida ativa da Fazenda Pública, inclusive no que concerne às causas interruptivas e suspensivas da prescrição.

Ora, com essa nova redação, o legislador retirou definitivamente a possibilidade de conversão da dívida advinda da pena de multa em pena privativa de liberdade, obedecendo aos ditames da Carta Republicana e deixando claro que caso não se haja o pagamento da multa, ela deverá ser cobrada como qualquer outra dívida, ou seja, por meio de ação de execução fundada em título judicial.

Por essa razão, a autoridade competente para executar o título judicial seria a Fazenda Pública, pois havia o impasse de que o Órgão competente para executar a dívida seria o Ministério Público.

Foi o que o ínclito jurista Miguel Reale Júnior ${ }^{45}$ explicitou: prevaleceu a orientação no sentido de que havia ocorrido a transferência da titularidade para a procuradoria da Fazenda Pública, devendo a multa ser inscrita como divida ativa a favor da Fazenda, se não paga após ter sido o condenado a fazê-lo, nos termos do art. $164^{46}$ da Lei de Execução Penal.

Nesse mesmo sentido, confirma Renato Marcão $^{47}$ que o Ministério Público não é mais parte legítima para promover a execução, e sim a Fazenda Pública, ficando o processo executivo submetido aos trâmites da Lei 6.830/90. E o juízo competente para execução é a Vara da Fazenda Pública estadual.

\subsubsection{Do livramento da condicional}

O conceito do livramento condicional da pena está devidamente delimitado nas palavras de José Frederico Marques, citado por Renato Marcão, como sendo a liberdade

45 REALE Jr., Miguel. Instituições de direito penal: parte geral. 2. ed. Rio de Janeiro: Forense 2004. v. 2 , p. 75.

46 Lei n. 7.210 Art. 164. Extraída certidão da sentença condenatória com trânsito em julgado, que valerá como título executivo judicial, o Ministério Público requererá, em autos apartados, a citação do condenado para, no prazo de $10(\mathrm{dez})$ dias, pagar o valor da multa ou nomear bens à penhora. $\S 1^{\circ}$ Decorrido o prazo sem o pagamento da multa, ou o depósito da respectiva importância, proceder-se-á à penhora de tantos bens quantos bastem para garantir a execução. $\S 2^{\circ}$ A nomeação de bens à penhora e a posterior execução seguirão o que dispuser a lei processual civil.

47 MARCÃO, Renato. Lei de execução penal: anotada e interpretada. 3. ed. Rio de Janeiro: Lumen Juris, 2009. p. 452 . 
provisória concedida, sob certas condições, ao condenado que não revele periculosidade, depois de cumprida uma parte da pena que lhe foi imposta. É dessa forma, um direito subjetivo do condenado.

Os requisitos para o livramento da condicional, ao sentenciado a pena privativa de liberdade igual ou superior a dois anos, estão dispostos no artigo 83 do Código Penal, desde que: cumprida mais de um terço da pena se o condenado não for reincidente em crime doloso e tiver bons antecedentes; cumprida mais da metade se o condenado for reincidente em crime doloso; comprovado comportamento satisfatório durante a execução da pena, bom desempenho no trabalho que lhe foi atribuído e aptidão para prover à própria subsistência mediante trabalho honesto; tenha reparado, salvo efetiva impossibilidade de fazê-lo, o dano causado pela infração; cumprido mais de dois terços da pena, nos casos de condenação por crime hediondo, prática da tortura, tráfico ilícito de entorpecentes e drogas afins, e terrorismo, se o apenado não for reincidente específico em crimes dessa natureza. Quanto ao condenado por crime doloso, cometido com violência ou grave ameaça à pessoa, a concessão do livramento ficará também subordinada à constatação de condições pessoais que façam presumir que o liberado não voltará a delinqüir.

A condição precípua do livramento condicional está na necessária condenação com pena igual ou superior dois anos. Os incisos I a V elencam as condições para o livramento nos diversos casos como o réu primário, o reincidente, o que reparou o dano, o condenado pelo cometimento de crime hediondo.

Todavia, o parágrafo único do art. 83 é visto de forma negativa para alguns juristas, pois entende-se incompatível com a sistemática adotada pelo Código Penal, vez que não mais se adota o direito penal do autor e, conforme a jurista Janaina Paschoal, ${ }^{48}$ qualquer ilação relativa à possibilidade de o condenado voltar a delinqüir implica realizar juizos de periculosidade, que são inconstitucionais e divorciados do Direito Penal do Fato.

O livramento condicional está, igualmente, ligado aos ditames do art. $132 \mathrm{da}$ Lei de Execuções Penais em que deferido o pedido, o Juiz especificará as condições a que fica subordinado o livramento. Além disso, serão sempre definidas ao liberado condicional as obrigações seguintes: obter ocupação lícita, dentro de prazo razoável se for apto para o trabalho; comunicar periodicamente ao Juiz sua ocupação; não mudar do território da comarca do Juízo da execução, sem prévia autorização deste. Outrossim, poderão ainda ser impostas ao liberado condicional, entre outras obrigações, as seguintes: não mudar de residência sem comunicação ao Juiz e à autoridade incumbida da observação cautelar e de proteção; recolher-se à habitação em hora fixada; não freqüentar determinados lugares.

48 PASCHOAL, Janaina Conceição. Direito Penal - Parte Geral. São Paulo: Manole, 2003, p. 158. 
Assim, a sentença proferida pelo magistrado dará as especificações necessárias a que fica subordinado o livramento e as penas referentes às infrações diversas deverão ser somadas, e ainda, poder-se-á haver a revogação do livramento se o liberado deixar de cumprir qualquer das obrigações constantes da sentença, ou for irrecorrivelmente condenado, por crime ou contravenção, a pena que não seja privativa de liberdade.

Ademais, necessariamente haverá a revogação do livramento quando o liberado vem a ser condenado a pena privativa de liberdade irrecorrível por crime hediondo durante a vigência do benefício ou ainda por crime anterior, observado os ditames do artigo 84 do Código Penal relativo à soma das penas.

Uma vez revogado o livramento, o Código Penal não admite nova concessão, exceto quando a revogação resulta de condenação por outro crime anterior àquele benefício, não se desconta na pena o tempo em que esteve solto o condenado.

E, nos termos do artigo 89 e 90 do Código Penal, o juiz não poderá declarar extinta a pena, enquanto não passar em julgado a sentença em processo a que responde o liberado, por crime cometido na vigência do livramento. E se até o seu término o livramento não é revogado, considera-se extinta a pena privativa de liberdade.

\subsubsection{Das faltas disciplinares}

Praticada a falta disciplinar (por exemplo, um preso é vistoriado e em sua cela encontrado um aparelho de celular) deverá ser instaurado o procedimento para sua apuração, conforme regulamento, assegurado o direito de defesa, existindo decisão motivada, nos termos do art. 59 da Lei de Execuções Penais.

Assim, dever-se-á instaurar uma regular sindicância para que a autoridade administrativa apure a real existência da falta grave. E ainda, como uma das exceções ao princípio da judicialização, o art. 47 da Lei n. 7.210 permite que a autoridade administrativa tenha o poder de disciplinar na execução da pena privativa de liberdade, conforme as disposições regulamentares. São elas, pois, que estabelecem os regulamentos, impõe as sanções e concedem as recompensas, interferindo o juiz da execução apenas em casos de infringência às normas estabelecidas pela lei ou pelo regulamento. ${ }^{49}$ Se não há qualquer irregularidade no procedimento instaurado, não há que se cogitar de desconsideração da falta disciplinar. ${ }^{50}$

\footnotetext{
Júlio Fabbrini Mirabete, Execução Penal, p. 132/133.

"O controle judicial dos atos administrativos é unicamente de legalidade. A justiça somente anula atos ilegais, não podendo revogar atos inconvenientes ou inoportunos, mas formal e substancialmente legítimos, porque isto é atribuição exclusiva da Administração"(Hely Lopes Meirelles, Direito Administrativo Brasileiro, pág. 167).
} 
Cumpre ressaltar, em idéia oposta, que, conforme os ensinamentos de Guilherme de Souza Nucci: ${ }^{51}$ (...) ainda que a conclusão do procedimento administrativo seja pela imposição de sanção disciplinar, pode o juiz da execução rever não somente a sanção, mas também as suas conseqüencias, isto é, deixar de considerar a falta para fim de prejuizo na execução da pena.

Pois bem, em se encaixando no rol taxativo do art. 50 da LEP, mais especificamente inciso VII, como se pode inferir a seguir, configura-se a falta grave: tiver em sua posse, utilizar ou fornecer aparelho telefônico, de rádio ou similar, que permita a comunicação com outros presos ou com o ambiente externo.

Portanto, no presente caso, em se tratando de posse de um aparelho de celular, permite-se concluir que é motivo para a classificação de uma falta grave o descrito no art. 50, inciso VII da LEP.

A prática de tal conduta acarretará, em tese, além das repercussões que causa na vida do estabelecimento e no quadro da execução, aduz Renato Marcão que, a falta grave justifica a regressão, logo transfere o condenado para um regime mais rigoroso do até então cumprido. E ainda, entende-se que a falta grave é equiparada à prática de fato definido como crime (art. 118, I da $\mathrm{LEP}^{52}$ ) e a sua existência obriga a autoridade administrativa a representar ao juiz da execução (parágrafo único ${ }^{53}$ do art. 48) para decisão da regressão, por conseguinte, há a judicialização.

Além disso, na determinação do art. 127 da LEP, o condenado que for punido por falta grave perderá o direito ao tempo remido, começando o novo período a partir da data da infração disciplinar, iniciando, nesse caso, novo período a partir da data de infração disciplinar.

Pode, inclusive, interromper com o cometimento de uma falta grave o lapso temporal, havendo o reinicio do cômputo do prazo de 1/6 de pena para obtenção de nova progressão de regime prisional (STF, HC 86.990-0/SP, $1^{\text {a }}$ T., rel. Min. Ricardo Lewandowski, DJ, 9-6-2006).

\subsubsection{Das saídas temporárias}

Agora, supondo o cumprimento de pena de quatro anos de reclusão em regime semiaberto. E o preso cumprido seis meses de pena e feito o pedido de "saída

\footnotetext{
51 NUCCI, Guilherme de Souza. Manual de processo penal e execução penal. 5. ed. rev., atual. e ampl. 2. tir. São Paulo: Editora Revista dos Tribunais, 2008. p. 1.025.

52 Art. 118. A execução da pena privativa de liberdade ficará sujeita à forma regressiva, com a transferência para qualquer dos regimes mais rigorosos, quando o condenado: 1 - praticar fato definido como crime doloso ou falta grave;

53 Parágrafo único. Nas faltas graves, a autoridade representará ao Juiz da execução para os fins dos artigos 118 , inciso I, $125,127,181, \S \S 1^{\circ}$, letra d, e $2^{\circ}$ desta Lei.
} 
temporária" para o juiz da Vara de Execuções Penais para passar a Páscoa com seus familiares, com a ressalva de ser reincidente e com bom comportamento.

Nos termos do art. 122 da Lei n. 7.210 de 1984, os condenados que cumprem pena em regime semi-aberto poderão obter autorização para saída temporária do estabelecimento, sem vigilância direta, nos seguintes casos: visita à família; freqüência a curso supletivo profissionalizante, bem como de instrução do $2^{\circ}$ grau ou superior, na Comarca do Juízo da Execução; e participação em atividades que concorram para o retorno ao convívio social. Assim temos um rol taxativo e sem qualquer possibilidade de ampliação.

A saída temporária é um direito público subjetivo restrito aos condenados que cumprem pena em regime semi-aberto e para que tal direito seja concedido, é necessário o cumprimento de requisitos legais do art. 123, que será outorgado por ato do Juiz da execução e ouvidos o Ministério Público e a administração penitenciária desde que: haja comportamento adequado; cumprimento mínimo de 1/6 (um sexto) da pena, se o condenado for primário, e 1/4 (um quarto), se reincidente; compatibilidade do beneficio com os objetivos da pena.

A mencionada concessão será por prazo não superior a 7 dias, podendo ser renovada por mais 4 vezes durante todo o ano, mas, em se tratando de curso profissionalizante, de instrução de $2^{\circ}$ grau ou superior, o tempo de saída será o necessário para o cumprimento das atividades discentes, conforme o art. 124 da Lei.

A revogação desse direito é possível e será automática quando o condenado praticar fato definido como crime doloso, for punido por falta grave, desatender as condições impostas na autorização ou revelar baixo grau de aproveitamento do curso. E a recuperação do direito à saída temporária, por sua vez, dependerá da absolvição no processo penal, do cancelamento da punição disciplinar ou da demonstração do merecimento do condenado.

Preenchendo o condenado o requisito do inciso I do art. 123 da LEP por possuir bom comportamento, é compatível com os objetivos funcionais da pena, vez que se trata de visita à família na comemoração da Páscoa, portanto, completa o disposto no inciso III do mesmo artigo.

Todavia, pelo fato do condenado ser reincidente, faz-se o cálculo do cumprimento da pena a partir da leitura da segunda parte do inciso II do art. 123 da Lei n. 7.210, logo o sentenciado deve ter cumprido no mínimo $1 / 4$ (um quarto) da pena.

Dessa forma, a pena total sendo de 4 anos (48 meses), 1/4 (um quarto) da pena é equivalente ao cumprimento mínimo de 1 ano ou 12 meses e pela data da solicitação da "saída temporária" não houve o cumprimento do requisito do art. 123, inciso II da LEP, portanto, o condenado não tem o direito ao benefício, vez que cumpriu quantidade de pena inferior à exigida em Lei. 


\subsubsection{Dos Regimes Disciplinares Diferenciados (RDD)}

Quanto à legitimidade, de primeira leitura ao art. 54, $\S 1^{\circ}$ da LEP, afere-se que a decisão para a inclusão no regime disciplinar diferenciado é jurisdicional, sendo, pois, competência do juiz da execução penal, porém não pode o magistrado decretar a inclusão ex officio, tampouco tem, nos ensinamentos de Renato Marcão, ${ }^{54}$ o Ministério Público legitimidade para postular a inclusão no RDD.

Aduz o mencioando jurista que a legitimidade para postular a inclusão no regime disciplinar diferenciado é do diretor do estabelecimento penal em que se encontre o preso provisório ou condenado-alvo, ou de outra autoridade administrativa, incluindo-se aqui autoridades como o Secretário da Segurança Pública e o Secretário da Administração Penitenciária. O requerimento deverá sempre circunstanciado, entenda-se fundamentado.

Em posição diametralmente oposta, segundo o texto para leitura, a LEP não atribuiu exclusividade ao diretor da unidade prisional ou a outra autoridade da Secretaria da Administração Penitenciária o pedido de inclusão no RDD. Ele pode ser formulado por outra autoridade administrativa que atue no sistema penitenciário, estando aí incluído o membro do Ministério Público com atribuição na Vara das Execuções Criminais.

Explanando tal tese, a função administrativa é exercida por 5 (cinco) entes: Poder Executivo (função administrativa típica), Poderes Legislativo e Judiciário (função administrativa atípica), Tribunais de Contas (que são órgãos auxiliares do Poder Legislativo) e o Ministério Público. Assim, o Promotor de Justiça, atuando como “custus legis", não deixa de ser autoridade administrativa.

Entende-se como função administrativa o exercício de atividades pelo Estado que visam a atender interesses de terceiros (a sociedade), dando aplicação efetiva à lei. O Ministério Público atua como fiscal da correta aplicação da lei, nos termos do art. 129, inciso II como função institucional do órgão zelar pelo efetivo respeito dos Poderes Públicos e dos serviços de relevância pública aos direitos assegurados nesta Constituição,promovendo as medidas necessárias a sua garantia, combinado com o art. $6^{\circ}$ elencando como sendo os direitos sociais a educação, a saúde, o trabalho, a moradia, o lazer, a segurança, a previdência social, a proteção à maternidade e à infância, a assistência aos desamparados, na forma desta Constituição, ambos da Constituição Federal, e com o art. 67 da Lei de Execução Penal em que o Ministério Público fiscalizará a execução da pena e da medida de segurança, oficiando no processo executivo e nos incidentes de execução.

54 MARCÃO, Renato. Lei de execução penal anotada e interpretada. 3. ed. Rio de Janeiro: Lumen Juris, 2009. p. 127. 
Conclui-se que é legítimo o Ministério Público requerer inclusão de preso no regime disciplinar diferenciado, vez que é o responsável pela fiscalização e correta aplicação dos dispositivos da LEP, sem dúvida, detém legitimidade para requerer medidas que propiciem a adequada segurança da unidade e do sistema prisional.

$\mathrm{E}$, quanto ao prazo máximo de internação do condenado, tem-se o disposto nos termos do inciso I do art. 52 da LEP, que determina: duração máxima de trezentos e sessenta dias, sem prejuizo de repetição da sanção por nova falta grave de mesma espécie, até o limite de um sexto da pena aplicada.

Não se pode interpretar o inciso de forma que o preso somente seja sancionado uma única vez no RDD e, posteriormente, possa receber nova inclusão pelo prazo máximo de sessenta dias, desde que a primeira punição tenha sido no limite estipulado de 360 dias. Deve-se inferir, da letra da Lei, que se trata do período de cumprimento do RDD, ou seja, se o preso tiver uma inclusão no prazo de 180 , portanto inferior a 360 dias, e cometer nova falta grave poderá ser imposta nova inclusão ao RDD até um prazo de um sexto desse montante, logo 30 dias. A prorrogação depende do tempo que o preso teve sua inclusão no RDD, dentro do período de 1/6 do total.

Entende-se também que não se é necessário o cometimento de nova falta grave de mesma espécie para ser incluído no RDD, bastaria uma nova falta grave, por exemplo, a primeira, homicídio, a segunda, cárcere privado, vez que ambas podem causar subversão à ordem e a disciplina da unidade ou do sistema prisional.

A autoridade competente para decretar a internação está em uma Resolução do Conselho Superior da Magistratura em que todo período do RDD se processe na Vara das Execuções Criminais da Capital por questão de segurança e para descentralizar a déia de um único magistrado, como existe nas Comarcas do interior.

Foi publicado no Diário Oficial do Estado de SP, Justiça, de 6/12/2004, Caderno 1, Parte I, p. 1 o Provimento 895/2004, estabelecendo a competência para apreciação dos pedidos de inclusão de presos no regime instituído pela Lei n. 10.792, de 1 de dezembro de 2003.

\subsubsection{Das medidas de segurança}

O Título VI da Parte Geral do Código Penal explicita o assunto relativo à medida de segurança. Explicam os juristas Delmanto ${ }^{55}$ que as medidas de segurança são também sanções penais e que, por vezes, acabam por assumir caráter mais gravoso do que as próprias penas, dada a severíssima restrição à liberdade da pessoa internada,

ss DELMANTO, Celso; DELMANTO, Roberto; DELMANTO JÚNIOR, Roberto; DELMANTO, Fabio M. de Almeida. Código penal comentado. 7. ed. Rio de Janeiro: Renovar, 2007. p. 271-272. 
sendo impostas como decorrência do poder de coação estatal (ius puniendi), em razão du prática, devidamente comprovada, de um fato penalmente típico e antijurídico, por uma pessoa considerada inimputável ou semi-imputável.

A Lei n. 7.209/84 introduziu na legislação penal o sistema vicariante ou unitário, em que apenas pode ser aplicada uma das sanções, pena ou medida de segurança aos semi-imputáveis e somente pena aos imputáveis, de acordo com os ensinamentos de Mirabete.

Além disso, o mencionado doutrinador explica que ficou demarcado o caráter exclusivamente preventivo e assistencial da medida de segurança, aplicada em decorrência da periculosidade, distinto do fundamento da imposição da pena, que é a culpabilidade.

A medida de segurança pode variar em duas espécies: a internação em hospital de custódia e tratamento psiquiátrico, na falta deste, outro estabelecimento adequado, e a sujeição a tratamento ambulatorial.

Tem-se o instituto da desinternação progressiva, que foi regulada pela Lei 10.216 de 2001, dispondo sobre a proteção e os direitos das pessoas portadoras de transtornos mentais e redireciona o modelo assistencial em saúde mental, juntamente com a Resolução 05/2004 do Conselho Nacional de Política Criminal e Penitenciária, que dispunha a respeito das Diretrizes para o cumprimento das Medidas de Segurança

Desinternação progressiva é uma espécie de progressão de regime para quem cumpre sanção de medida de segurança (medida aplicada apenas para os doentes mentais). É um tratamento diferenciado, em obediência ao princípio da individualização da pena, oferecido ao condenado que possui transtornos psiquiátricos para que ele tenha condições a ser reintegrado à sociedade, por meio de saídas dos hospitais nos fins de semana e feriados, mas para o benefício de tal regime, o sentenciado precisa ser aprovado em uma perícia médica que ateste sua não-periculosidade.

No caso de um inimputável, o art. 97, parágrafo $1^{\circ}$, da LEP, impõe que a desinternação, ou a liberação, será sempre condicional devendo ser restabelecida a situação anterior se o agente, antes do decurso de 1 (um) ano, pratica fato indicativo de persistência de sua periculosidade.

Na diretriz n. 12 da Resolução 05/2004 do CNPCP, houve o estabelecimento de que a medida de segurança deve ser aplicada de forma progressiva, por meio de saídas terapêuticas, evoluindo para regime de hospital-dia ou hospital-noite e outros serviços de atenção diária tão logo o quadro clínico do paciente assim o indique. A regressão para regime anterior só se justificará com base em avaliação clínica.

Tanto se aplica a desinternação progressiva, quanto a regressiva como podemos inferir pelo julgado: 
Se no curso do benefício (da desinternação condicional) passou a ameaçar a família, restabelece-se a medida de segurança. (TJSP, RJTJSP 118/553) (adendo à parte).

Assim, a desinternação progressiva tem o fito de reinserir socialmente o paciente em seu meio. Ela é aplicável tanto no sentido progressivo quanto no regressivo e sempre havendo laudo pericial médico para motivar qualquer modificação no regime adotado.

Quanto à prescrição da medida de segurança, é por óbvio que a medida de segurança está sujeita à prescrição, pois, conforme a Carta Magna, o caso cuja sanção penal é imprescritível é o disposto no art. $5^{\circ}$ incisos XLII e LXIV, veja-se pelo entendimento do julgado do Rel. Eduardo Goulart:

O Sistema Legal Brasileiro não prevê nenhuma pena ou qualquer outro tipo de sanção penal imprescritível, à exceção da prática do racismo e da ação de grupos armados contra a ordem constitucional e o estado democrático, nos termos do art. $5^{\circ}$, XLII e LXIV, da Constituição Federal, sendo certo que, qualquer que seja a posição que se adote quanto à natureza da medida de segurança, não se pode negar contenha ela carga sancionatória, pois seria um absurdo se tal medida fosse destituída do mencionado efeito, e que pessoas consideradas doentes mentais fossem coercitivamente internadas em manicômios até que se verificasse a cessação do estado dito perigoso para a sociedade, admitindo-se, portanto, a prescrição das medidas de segurança. Habeas Corpus n ${ }^{\circ} 389.934 / 2$ - São Paulo - $1^{\text {a }}$ Câmara Relator: Eduardo Goulart - 2/8/2001 V.U. (Voto

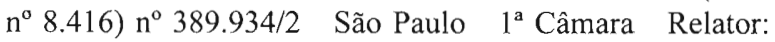
Eduardo Goulart - 2/8/2001 V.U. (Voto ${ }^{\circ} 8.416$ )

$\mathrm{O}$ art. 96 do Código Penal, em seu parágrafo único, estatui que extinta a punibilidade, não se impõe a medida de segurança, nem subsiste a que tenha sido imposta. Assim, corrobora que a prescrição é uma das causas extintivas de punibilidade.

É o que se depreende pelos julgados:

A medida de segurança, em razão de ser agente inimputável, é inaplicável se ocorreu a prescrição da pretensão punitiva (TACrSP, Julgados 87/63);

Se ocorre a extinção da punibilidade, em quaisquer de suas hipóteses e não só em caso de prescrição, não se aplica a medida de segurança. (TJSP, RT 623/292).

Todavia, o Código Penal não estabelece qual o prazo prescricional da medida de segurança, tampouco qual o critério a ser utilizado para seu cômputo. Dessa forma, o professor Miguel Reale Jr. entende que pelo fato de não haver uma determinação legal para fixação de prazo de prescrição de medida de segurança, a doutrina fixou-se no 
critério da pena máxima cominada ao tipo legal de crime, seja para a prescrição anterior ou posterior à sentença, devendo-se por coerência entender que a sentença impositiva de medida de segurança, por ser condenatória, interrompe a prescrição.

É o que também complementa Mirabete, pois a prescrição é regulada sempre pelo máximo da pena em abstrato, já que não há mais possibilidade de aplicação concomitante de pena e medida de segurança. Inexistindo pena in concreto, a prescrição somente pode ser fundada no máximo da pena in abstracto. Por essa razão, aliás, não se repete na lei nova a regra anterior, pela qual se extinguia a medida de segurança não executada pelo prazo de cinco anos, contados do cumprimento da pena se o condenado, nesse periodo, não cometesse novo crime.

Portanto, deve-se prevalecer o critério da pena máxima cominada e não o da pena mínima, entendendo-se ser a melhor solução com os objetivos de tratamento e de defesa da sociedade, em se adotando concomitantemente o art. 109 do Código Penal, cujo seu caput informa que a prescrição, antes de transitar em julgado a sentença final, salvo o disposto nos $\S \S 1^{\circ} \mathrm{e} 2^{\circ}$ do art. 110 do Código, regula-se pelo máximo da pena privativa de liberdade cominada ao crime, uma vez que a medida de segurança se trata de uma pena, por essa razão a conduta de acordo com os ditames do artigo mencionado.

Todavia, a jurisprudência mais razoável, em se tratando de inimputáveis e semi-imputáveis, leva em conta o prazo mínimo da sanção penal demarcada na sentença, entendendo-se com uma internação de um a três anos.

Foi a conclusão do julgado em que:

\begin{abstract}
Essa conclusão parece ser a melhor que se coaduna com a ausência de diferença ontológica entre a pena e a medida de segurança, posto que ambas têm a mesma gênese, isto é, de sanção penal. Não fosse assim, estar-se ia vilipendiando o princípio isonômico (cf. art. $5^{\circ}$, caput, da CF), admitindose a ocorrência da prescrição, tanto para o mais execrável dos criminosos plenamente imputável, e retirando-se igual direito daquele que, atormentado por uma doença mental, veio a cometer à guisa de exemplo, o mesmo fato típico endereçado àqueles. (Ap. 1.401.977/2, j. 3.8.2005, in Bol. IBCCr no. 157, dezembro de 2005)
\end{abstract}

Assim sendo, nada mais coerente, em se tratando de pessoas inimputáveis ou semi-imputáveis, a adoção da prescrição mais razoável seria o prazo da pena mínima, pois haver-se-ia, se aplicada o caso da pena máxima, não só desproporcionalidade em relação ao condenado são de seus atos em relação àquele debilitado mentalmente, como também um desrespeito aos direitos e garantias fundamentais, principalmente ao princípio da igualdade do art. $5^{\circ}$ da Constituição Federal. 


\subsubsection{Do recurso na lei de execuções penais}

Veja-se o exemplo de um sentenciado " $X$ ", condenado a pena de 05 anos e 04 meses de reclusão, pela prática de roubo qualificado, que requereu a progressão ao regime semi-aberto. Embora tenha cumprido o lapso temporal exigível, de um sexto da pena, "X" não ostenta bons antecedentes e, mesmo assim, o Juiz deferiu a progressão.

Caso não se aceite a decisão do magistrado, o recurso cabível é o agravo em execução contra a decisão de deferimento de progressão de regime prisional, conforme RT 773/609. Nesse sentido foi a decisão do RJDTACrimSP 40/357 remete a o recurso cabivel das decisões proferidas em sede de execução criminal é o de agravo. A forma de interposição do recurso deve ser perante o juiz de primeiro grau, pode-se ter sua subida nos próprios autos à superior instância, sem prejuízo da execução, sendo, portanto, desnecessária a formação de instrumento.

Urge salientar que, não havendo previsão legal específica para o agravo em execução penal, é aplicável a teoria da fungibilidade dos recursos contido no artigo 579 do Código de Procedimento Penal, evidentemente, excluída qualquer má-fé no desatendimento da formalidade e prejuízo às partes. Assim, há julgados dando procedência a interposição de recurso em sentido estrito (RT 660/309), correição parcial (RJDTACrimSP 37/395), mandado de segurança (RT 760/754).

Quanto ao prazo para interposição do recurso, é de 5 dias, uma vez que a jurisprudência já possui sua posição sedimentada em que se deve seguir o rito do recurso em sentido estrito, além do mais, a questão já está sob a forma de Súmula proferida pelo STF em sua Súmula 700, cuja transcrição nos remete ao seguinte: $E$ de cinco dias o prazo para interposição de agravo contra decisão de juiz da execução penal.

Ademais, em tese, não há efeito suspensivo, salvo no caso de decisão que determina a desinternação ou liberação de quem cumpre medida de segurança, e tem seu processamento segundo os ditames legais do recurso em sentido estrito. Esse é o entendimento do julgado do STJ, HC 6.642-SP, $6^{\mathrm{a}}$ T., rel. Min. Vicente Leal, j. 10-3-1998, v.u. DJU, 6 abr. 1998, p.161. - (ver art. 179)

Conforme os ensinamentos de Mirabete, ${ }^{56}$ não concedeu a lei ao agravo em execução o efeito suspensivo sob o fundamento de que, como regra geral, não haverá dano enquanto se aguarda a decisão do recurso interposto pela parte, sua posição, dessa forma é de que não há o efeito suspensivo.

Há a possibilidade, portanto, de se ter o efeito suspensivo em casos excepcionais como o determinado no artigo 179 da LEP, porém, pleiteando tal efeito e havendo sua denegação, deve-se tomar a providencia impetrando um Mandado de

56 MIRABETE, Julio Fabrini. Execução penal. 11. ed. São Paulo: Atlas, 2007. p. 820. 
Segurança, desde que presentes o fumus boni juris e o periculum in mora. Todavia, há que se ressaltar a existência de correntes jurisprudências pela ilegitimidade do MP em impetrar o remédio constitucional e, de outro diapasão, os defensores da legitimidade do Promotor de Justiça para a impetração do mandado de segurança.

E o rito a ser adotado do recurso de agravo em execução é o mesmo do recurso em sentido estrito, conforme indica Mirabete: ${ }^{57}$ na jurisprudencia, o entendimento praticamente pacífico é o de que deve ser seguido o rito do recurso em sentido estrito.

\subsection{Aspectos relevantes e omissos da Execução Penal}

7.2.1. O direito à visita íntima dos presidiários

A LEP não explicitou em seu artigo 41 como direito do preso a "visita íntima" o que deixa em dubiedade se seria de fato um direito ou tão somente uma faculdade do presídio em permitir ou não.

Entretanto, deve-se interpretar o referido artigo com eficácia contida, isto é, deve-se levar em consideração os dispostos nas Regras Minimas da ONU para o Tratamento de Reclusos, adotadas em 31 de agosto de 1955, pelo Primeiro Congresso das Nações Unidas para a Prevenção e o Tratamento dos Delinquentes; a Resolução n. 14 do Conselho Nacional de Política Criminal e Penitenciária, de 11 de novembro de 1994, acerca das Regras Minimas para o Tratamento do Preso no Brasil; o Pacto de Sano José da Costa Rica no que concerne ao direito à integridade pessoal; e, principalmente, a Resolução n. 1, de 30 de março de 1999, do Conselho Nacional de Política Criminal e Penitenciária que recomendou aos Departamentos Penitenciários Estaduais ou órgãos congêneres o direito à "visita íntima" aos presos de ambos os sexos recolhidos aos estabelecimentos prisionais.

Dessa forma, por meio dessa Resolução de 1999, ou seja, 15 anos após a Lei de Execução Penal, tal direito aos presos foi parcialmente reconhecido pela mencionada recomendação, logo não necessariamente devem os estabelecimentos penais acatar.

\subsubsection{A progressão de regime dos condenados estrangeiros}

Discute-se se os condenados estrangeiros podem obter a progressão de regime. Ainda prevalece o entendimento que a progressão ao regime semi-aberto e o livramento condicional são incompatíveis com a situação do estrangeiro, mas o STJ vem mudando posicionamentos anteriores e admitindo a possibilidade de progressão de regime

\footnotetext{
$57 \quad$ Idem, p. 819.
} 
e livramento condicional. De outro lado, o Ministério Público continua manifestando-se contrário a tais benefícios para estrangeiros que estão em situação irregular no país.

É uma questão delicada, pois uma vez obtida a progressão de regime, nada garante que o condenado estrangeiro permaneça no Brasil ou fuja para outro país. Não há meios para garantir a eficácia de seu cumprimento.

7.2.3. O laudo criminológico para fins de progressão, requerido pelo Ministério Público

Incorreto afirmar que a Lei n. 10.792/2003 excluiu o exame criminológico. Mesmo após a mudança legislativa, tal exame ainda é exigível, a teor do disposto no art. $5^{\circ}$ e art. $8^{\circ}$ da LEP, com o fim de orientar a classificação dos condenados e a individualização da execução penal. O exame criminológico não se destina unicamente para a aferição do mérito para progressão de regime e outros benefícios.

A extinção do exame criminológico, para progressão e outros benefícios, tornou o procedimento mais célere, mas a demora na análise do pedido deveria ter sido combatida com a contratação de novos profissionais, criação de novas equipes e não com o fim do exame. A avaliação tem suma importância para verificação da aptidão do sentenciado para o benefício desejado.

Pelo entendimento uníssono do Grupo de Trabalho de Execuções Criminais da Procuradoria Geral de Justiça: será solicitado exame criminológico na progressão e no livramento condicional para condenados por crimes hediondos, delitos com violência à pessoa, reincidentes ou com péssimos antecedentes, integrantes de organizações criminosas, recomendando-se a fundamentação em face do caso concreto. O pedido de exame criminológico - nessas hipóteses, seja requerido na primeira manifestação a respeito do pleito do benefício e de forma fundamentada.

\subsubsection{A remição da pena por estudo}

Embora a LEP explicite no art. 126 que a remição se dará pelo trabalho, em se tratando de frequência de estudo a curso de ensino formal, entende-se como sendo possível tal benefício, vez que não deixa de ser uma forma de cumprir com a "harmônica integração social do condenado" Assim é possível nos conceitos sedimentados pela Súmula 341 do Superior Tribunal de Justiça.

Deve-se ter, portanto, uma interpretação analógica e sistêmica estendendose o entendimento de que o apenado quando frequenta um curso, é uma forma também de se ressocializar, não se deve ater à literalidade da legislação, ora, não se pode desamparar o condenado descumprindo os princípios da Lei de Execuções Penais. 


\subsubsection{A possível inconstitucionalidade do Regime Disciplinar Diferenciado (RDD)}

Relevante discussão pousa sobre a constitucionalidade do RDD do art. 52 da Lei e seus incisos e parágrafos, pois em julgados que poderia se tratar de uma determinação desumana e degradante chegando a ser cruel. Decidiu-se o seguinte:

(...) O chamado RDD (Regime disciplinar diferenciado), é uma aberração jurídica que demonstra à sociedade como o legislador ordinário, no afã de tentar equacionar o problema do crime organizado, deixou de contemplar os mais simples princípios constitucionais em vigor. (...) Independentemente de se tratar de uma política criminológica voltada apenas para o castigo, e que abandona os conceitos de ressocialização ou correção do detento, para adotar "medidas estigmatizantes e inocuizadoras" próprias do "Direito Penal do Inimigo", o referido "regime disciplinar diferenciado" ofende inúmeros preceitos constitucionais". E continua o insigne Magistrado, "trata-se de uma determinação desumana e degradante (art. $5^{\circ}$, III, da CF), cruel (art. $5^{\circ}$, XLVII, da CF), o que faz ofender a dignidade humana (art. $1^{\circ}$, III, da CF). (...) O Conselho Nacional de Política Criminal e Penitenciária, ao entender como inconstitucional o citado regime disciplinar, ainda deixou evidente que a medida "é desnecessária para a garantia da segurança dos estabelecimentos penitenciários nacionais e dos que ali trabalham, circulam e estão custodiados, a teor do que já prevê a Lei 7.210/84. (Habeas Corpus $\mathrm{n}^{\circ}$ 978.305.3/0-00 - Primeira Câmara do TJSP)

Embora haja defesa no sentido da inconstitucionalidade do RDD, acordase que não haveria o ferimento aos princípios da presunção da inocência, tampouco da dignidade da pessoa humana, pois eles não seriam excluídos, mas sim, sopesados à luz do princípio da proporcionalidade em que o outro princípio de maior valor é preponderante sobre o de menor.

É com o fito de legitima atuação estatal, tendo em vista que a Lei $n$. 10.792/2003 alterou a redação do art. 52 da LEP, busca dar efetividade à crescente necessidade de segurança nos estabelecimentos penais, bem como resguardar a ordem pública, ameaçada por criminosos que, mesmo encarcerados, continuam comandando ou integrando fações criminosas atuantes no interior do sistema prisional - liderando rebeliōes culminadas por fugas e mortes de reféns, agentes penitenciários e/ou outros detentos - e, também, no meio social.

Ora, o Estado apenas está cumprindo com o seu dever da manutenção do equilíbrio social e o RDD é uma das formas necessárias para que tal escopo seja observado. Decerto ainda faltam muitas medidas a serem devidamente tomadas como superlotação nas carceragens, porém isolar presos provisórios ou definitivos devido ao seu grau de periculosidade é maneira eficaz para tentar romper os laços de mandoninsmo de 
dentro dos presídios com o mundo afora e evitar o nascimento de novas facções e rebeliões comandadas por esses "chefões"

\subsubsection{Os hospitais de custódia e tratamento}

No Estado de São Paulo, há apenas 3 hospitais de custódia e tratamento, conforme os dados da Secretaria da Administração Penitenciária do Estado de São Paulo, ${ }^{58}$ quais sejam, em Franco da Rocha - Hospital de Custódia e Tratamento Psiquiátrico "Professor André Teixeira Lima" - Franco da Rocha I (masculino e feminino); em Franco da Rocha - Hospital de Custódia e Tratamento Psiquiátrico - Franco da Rocha II; e em Taubaté - Hospital de Custódia e Tratamento Psiquiátrico "Dr. Arnaldo Amado Ferreira".

$O$ Ente Federativo Paulista com um grande número de presos que possui, perceptivelmente não pode oferecer o devido tratamento a todos os presidiários que necessitam desses estabelecimentos especializados, deixando, pois, à deriva aqueles que, por ventura, não conseguiram vaga. Diante dessa ausência estatal, temos os seguintes julgados:

Se a instituição oficial não pode proporcionar tratamento específico, permite-se que o insano fique em hospital que ofereça condições de custódia. (STF, RTJ 121/105)

"Falta de vaga: a ausência de vagas para internação em hospital psiquiátrico ou estabelecimento adequado não justifica o cumprimento de medida de segurança em cadeia pública; por isso, concede-se a liberdade provisória, mas condicionada a tratamento ambulatorial." (TJSP, RT 608/325)

Assim, cabe ao Ministério Público, munido com poderes que lhe são incumbidos constitucionalmente, mediante ação civil pública, agir em nome dos presos contra o Estado para que disponibilize vagas para todos.

\subsubsection{O recurso contra as decisões de juiz de execução penal}

O recurso contra as decisões proferidas pelo magistrado da execução penal será o de agravo, sem o efeito suspensivo, conforme os ditames do artigo 197 da Lei 7.210/84. E terá o juízo de primeiro grau como competente para a interposição.

Contudo, não explicita a Lei qualquer prazo ou procedimento adotado e em se tratando de uma Lei de execução e lidando com o status libertatis de um ser humano, deveria ser eficaz e bem escrita de tal forma a não haver lacunas. O recurso de agravo à execução que não está claramente exposto, pois pode-se valer do princípio da

$58 \quad$ http://www.sap.sp.gov.br/common/unidades.html 
fungibilidade dos recursos para sanar um eventual recurso diverso do previsto desde que atendida a finalidade.

Assim, por mais que se invoque o princípio da fungibilidade para efetivamente ter o recurso provido, há que se perceber a contingência de uma eventual demora nesse procedimento, pois caso não se aceite de pronto o recurso inapropriado, o réu terá seus direitos infringidos. Dessa forma, uma lei cristalina e objetiva, ainda mais quando toca assuntos de liberdade e humanidade, deve ser prioridade, infelizmente, não o foi quanto a esse tópico do recurso cabível.

8. A situação dos presídios brasileiros - uma visão panorâmica

A situação dos presídios não é um problema hodierno. Há tempos existem relatórios que delatam a vida precária nos presídios, bem como o descumprimento dos direitos humanos e a falta de preocupação de ressocialização dos sentenciados.

Em relatório ${ }^{59}$ elaborado pelas Comissões de Direitos Humanos das Assembléias Legislativas, Pastoral Carcerária - CNBB e outras entidades a partir de estudo feito em diversos estados brasileiros no ano de 2006, conclui-se que o problema mais comum é uma quantidade superior de presos em relação às vagas existentes nos presídios, a superlotação. Por exemplo, no Estado de São Paulo, havia para 144 unidades prisionais, 125.804 presos para 92.865 vagas; o Estado de Mato Grosso havia 4.661 vagas existentes para 7.150 presos, sendo que o número de presos condenados eram 3.333 e os presos provisórios 3.817; no Estado do Ceará havia 10.890 presos para 6.785 vagas em presídios existentes.

Além disso, em análise do relatório, o mais comum observado é o descaso com os direitos dos presos, bem com o descumprimento da Lei de Execução Penal, pois há desrespeito dos familiares nos dias de visitas, prática de tortura e espancamento, alimentação precária, falta de assistência jurídica, falta de assistência médica aos sentenciados doentes, falta de infraestrutura, insuficiência de programas de trabalho e ressocialização, débeis condições de higiene.

Em reportagem realizada pelo jornal Folha de S. Paulo, ${ }^{60}$ o Ministro Gilmar Mendes, que havia acabado de tomar a posse na presidência do Conselho Nacional de Justiça, afirmou ser a situação dos presídios uma vergonha nacional. Em outra reportagem ao mesmo jornal, ${ }^{61}$ o Ministro afirmou que a justiça e a sociedade deveriam agir para a ressocialização de ex-detentos. Havia, no período de setembro de 2008 , cerca de 9.000 condenados que já tinham cumprido pena, mas permaneciam, na grande maioria, atrás

Relatório: Situação do sistema prisional brasileiro. http://www.camara.gov.br/cdh FOLHA DE S. PAULO. São Paulo, 26 mar. 2008.

${ }_{61}$ FOLHA DE S. PAULO. São Paulo, 24 dez. 2008. 
das grades pela falta de defensores públicos que comunicassem a soltura do preso ao juiz. Afirmou o Ministro, em entrevista, que o preso quando libertado, sai sem nenhuma ajuda, não possui roupas ou trabalho, tornando-se presa fácil às organizações criminosas, razão pela qual deve a sociedade se conscientizar para a ressocialização, ante a ausência do Estado.

Segundo reportagem de 21 de março de $2009,{ }^{62}$ o Conselho Estadual de Direitos Humanos e a Pastoral do Menor no Espírito Santo cogitaram apresentar denúncia sobre a situação degradante dos presídios capixabas (Espírito Santo) à Corte Interamericana de Direitos Humanos, isso pelo fato da morosidade de tomada de decisões na melhoria carcerária. O Ministro da Justiça, Tarso Genro, à época dos incidentes, em resposta aos ocorridos naquele Estado disse "que o sistema penitenciário, "em geral" está falido no Brasil"

Toda a discussão acerca da situação dos presídios no Espírito Santo está pautada no fato dos encarcerados estarem com suas liberdades limitadas não por celas, mas por estarem em contêineres, o que fere, não só a dignidade da pessoa humana, como também a própria vida diante da insalubridade e tratamento degradante.

O secretário da justiça do estado capixaba, à época, Ângelo Roncalli, afirmou que 306 pessoas eram mantidas em contêineres no Presídio de Novo Horizonte, bairro do município da Serra. De acordo com ele, a "solução provisória" foi adotada no fim de 2007 para enfrentar o aumento da população carcerária e a necessidade de reformar ou mesmo fechar unidades prisionais com "problemas estruturais" 63

Ainda não se modificou a referida forma de carceragem, pois em reportagem de 09 de março de 2010, o mesmo jornal Folha de S. Paulo ${ }^{64}$ apontou a permanência da carceragem de "latinha" conforme pode-se aduzir pela transcrição de parte do relato: Quentes e improvisadas, as celas metálicas construidas em contêineres de transporte abrigam ainda 580 detentos (homens e mulheres) no Espirito Santo. O Centro de Detenção Provisória de Cariacica, na região metropolitana de Vitória, mantém 500 detentos em contêineres, e o presidio feminino de Tucum, na mesma cidade, abriga 80 mulheres em regime semiaberto nessas condições. "Não dá para esquecer os gritos de horror que ouvimos de dentro do Centro de Detenção de Cariacica. É uma situação de superlotação, calor e violência fisica" disse Tamara Melo, advogada da ONG Justiça Global, que fez uma inspeção no Estado em fevereiro.

Ora, ante tais irregularidades degradantes ao ser humano, é praticamente inviável seguir os belos princípios de leis como os da Lei de Execução Penal, que buscam

\footnotetext{
62 FOLHA DE S. PAULO. São Paulo, 21 mar. 2009.

63 FOLHA DE S. PAULO. São Paulo, 22 maio 2009.

${ }_{64}$ FOLHA DE S. PAULO. São Paulo, 9 mar. 2010.
} 
a ressocialização do preso, defendem uma permanência corretiva nas celas, e ainda, visam a dignidade da pessoa humana. De nada adianta uma Lei bem estruturada, humanizada, se não existir a real participação da sociedade em querer efetivar os ditames legais.

Há que se aceitar os ensinamentos de Tailson Pires Costa ${ }^{65}$ ao afirmar: Quando se tem, no lado de fora dos muros das prisões, uma Carta Constitucional que procura preservar ao máximo os direitos conquistados pelos cidadãos que estão sob suas regras e, em contrapartida, no lado interno destes muros, o descaso, a omissão, a complacência e também a convivência do próprio poder público em não respeitar os direitos fundamentais garantidos constitucionalmente, então é chegado o momento de admitir que aquilo foi uma dia uma grande conquista, hoje já é um sistema obsoleto e ultrapassado.

A situação dos presídios é caótica e o Estado apenas se demonstra conivente com essa forma de tratamento aos sentenciados corroborando sua ausência, agredindo-os de forma indireta, o que só dificulta o cumprimento os ditames da Lei n. 7.210/84.

\section{Conclusão - a fragilidade da Lei de Execução Penal}

A Constituição Federal, como cediço, é a Lei Fundamental irradiadora das máximas a serem seguidas, que delas, outras subsidiariamente seriam criadas. Nesse sentido, a Lei de Execução Penal possui em seu corpo importantes princípios constitucionalmente protegidos a serem tomados como norte a fim de dar a devida proteção aos condenados.

No art. $1^{\circ}$ da Lei n. 7.210/84, houve uma importante proteção aos sentenciados, que foi a busca da reintegração social harmônica do condenado ou internado à sociedade, deixando, ao mesmo tempo, o caráter da pena como sendo exclusivamente punitivo, mas sim algo com o fim de melhorar o indivíduo ao ponto de reintegrá-lo no meio social.

Para tanto, a Execução Penal invoca direitos e deveres do condenado, os estabelecimentos, cujas penas ou medidas de segurança seriam cumpridas, as funções dos órgãos incumbidos a fiscalizar e regular o cumprimento da sanção, a forma de execução das penas em espécie, as formas de execução das medidas de segurança, os incidentes de execução e o procedimento judicial a ser respeitado.

Contudo, embora a referida norma aparente a concretude de um ideal na execução da pena ou da medida de segurança, a realidade aponta para outro horizonte, que diverge da aspiração de uma reintegração eficaz de um indivíduo à sociedade.

65 COSTA, Tailson Pires. A dignidade da pessoa humana diante da sanção penal. São Paulo: Fiuza editores, 2004. p. 94-95. 
Ditames legais servem para assegurar juridicamente um caminho a ser trilhado, porém, à luz da realidade debatida no presente artigo, constata-se que nem mesmo o princípio da legalidade é cumprido quando, por exemplo, há falta de Casas de Albergado, ou de Hospitais de Custódia e Tratamento, ou então, quando se comprova, ante reportagens veiculadas em noticiários, que a situação carcerária é lastimável, denegrindo a imagem de um Estado incapaz de prover a mínima dignidade da pessoa humana aos condenados.

Ademais, não pode uma Lei, que trata assuntos delicados como o status libertatis de indivíduos, ser omissa no tocante à "visita íntima", a não discriminação devida sobre a remição da pena por estudo, a não explicitação do recurso cabível contra decisões de juiz de execução penal com prazos e forma, uma vez que a sua errônea interposição e a impossibilidade da utilização do princípio da fungibilidade, geraria uma delonga da situação prisional do sentenciado.

Pois bem, o desrespeito, principalmente ao princípio da dignidade da pessoa humana, é uma afronta aos direitos e garantias constitucionais fundamentais, aos direitos inerentes ao homem. É ferir uma possibilidade na construção de uma convivência social na qual se busca dirimir as desigualdades sociais, pois não é pelo fato de se perder a liberdade de locomoção e ter determinados direitos políticos restringidos que o indivíduo abandona a qualidade de ser humano.

Embora se saiba que a pena privativa de liberdade seja um conhecido malefício diante da situação degradante dos presídios e do descumprimento de muitos dizeres legais da Lei n. 7.210/84, inexiste outro meio eficaz a ponto de sê-la substituída, portanto, devemos conviver com tal cerceamento de locomoção, mas com uma mente projetada à verdadeira ressocialização do condenado, bem como pela real melhora da infraestrutura carcerária.

Além do mais, os estudos criminológicos comprovam que a própria cultura impõe limites, vedações ao ser humano tanto instintivas como materiais, oferecendo oportunidades a uma parcela reduzida, assim, nas palavras comedidas do jurista Alvino Augusto de Sá66 temos que só uma minoria, constituida pelos ricos e opressores, por alguns abençoados pela sorte é que tem a ganhar com as perdas sofridas, pois só eles compartilham dos beneficios, beneficios da terra e de todo o instrumental necessário para cultivá-la, do dinheiro, do trabalho digno e salário justo, beneficios da cultura, do conhecimento, da ciência, da filosofia, da arte, do lazer e muitos outros.

Dessa forma, o problema não é só interno, carcerário, legal. É também de uma civilização, de uma sociedade que deveria compreender a situação em momentos

66 SÁ, Alvino Augusto de. Criminologia clinica e psicologia criminal. São Paulo: Revista dos Tribunais, 2007. p. 149. 
anteriores ao cometimento do delito, isto é, a falta de oportunidades ou a inexistência estatal para dirimir a desigualdade de forças, poderia levar um indivíduo a liberar sua sublimação interna repressiva de forma contrária aos limites impostos pela cultura.

Há que se acatar à sábia e exemplar conduta do Ministro Gilmar Mendes, na exposição do ano de abertura do Judiciário de 2009, em transcrição pelo jornal Folha de S. Paulo, ${ }^{67}$ temos um exemplo de ressocialização e preocupação para com os presos e ex-presidiários, senão vejamos: A partir desse mês, o Supremo passa a contar com atuação de novos especiais colaboradores. São quarenta pessoas sentenciadas, egressas de prisões, que trabalharão de seis a oito horas por dia, dando suporte administrativo ao Tribunal, por até um ano. Em processo de ressocialização, merecem todo o nosso apoio para que, bem adaptados às suas funções, desempenhem dignamente as tarefas que lhe forem designadas e retornem com sucesso ao convivio social.

Talvez uma saída possivelmente eficaz seria o amparo, a preocupação do Estado na escolarização e capacitação de seus cidadãos com o fito de estimular o crescimento conjunto das diversas classes sociais. É trazer à tona a parcela desfavorecida financeira e intelectual junto às camadas de maior poder aquisitivo para que possa competir pelas mesmas oportunidades de forma a valer a dita igualdade constitucional.

Além disso, cumpre salientar que a Lei Execução Penal é controversa à realidade ao ditar condutas e princípios que não podem ser cumpridos ou por vacuidade da Lei, ou por falta de infraestrutura do sistema carcerário.

Sendo assim, urge uma atitude vigorosa de toda uma sociedade com a máxima de se mobilizar ao cumprimento dos ditames legais, de propor modificações normativas a fim de suprir lacunas, de entender que a população carcerária não perdeu a sua condição de ser humano, de buscar uma estruturação real prisional à reintegração social do condenado à pena ou à medida de segurança.

São Paulo, 31 de março de 2010.

\section{Referências}

ALEXY, Robert. Teoria dos direitos fundamentais. Tradução Luís Virgílio Afonso da Silva. São Paulo: Malheiros, 2008.

BARROS, Carmem Silvia de Moraes. A individualização da pena na execução penal. São Paulo: Revista dos Tribunais, 2001.

CAPEZ, Fernando. Curso de processo penal. 16. ed. São Paulo: Saraiva, 2009.

67 FOLHA DE S. PAULO. São Paulo, 2 fev. 2009. 
COSTA, Tailson Pires. A dignidade da pessoa humana diante da sanção penal. São Paulo: Fiuza editores, 2004.

DELMANTO, Celso; DELMANTO, Roberto; DELMANTO JÚNIOR, Roberto; DELMANTO, Fabio M. de Almeida. Código penal comentado. 7. ed. Rio de Janeiro: Renovar, 2007.

FOLHA DE S. PAULO, São Paulo, 02 fev. 2009.

FOLHA DE S. PAULO, São Paulo, 09 mar. 2010.

FOLHA DE S. PAULO, São Paulo, 21 mar. 2009.

FOLHA DE S. PAULO, São Paulo, 22 maio 2009.

FOLHA DE S. PAULO, São Paulo, 24 dez. 2008.

FOLHA DE S. PAULO, São Paulo, 26 mar. 2008.

GOMES FILHO, Antonio Magalhães. A motivação das decisões penais. São Paulo: Revista dos Tribunais, 2001.

GOMES, Luiz Flávio; MAZZUOLI, Valério de Oliveira. Comentários à Convenção Americana sobre Direitos Humanos. Pacto de San José da Costa Rica. 2. ed. São Paulo: Revista dos Tribunais, 2009. v. 4.

HORCAIO, Ivan. Dicionário Jurídico Referenciado. São Paulo: Primeira Impressão, 2006

JESUS, Damásio E. de. Código penal anotado. 11. ed. São Paulo: Saraiva, 2001.

JUNQUEIRA, Gustavo Octaviano Diniz; FULLER, Paulo Henrique Aranda. Legislação penal especial. 5. ed. São Paulo: Premier Máxima, 2008. v. 1.

MARCÃO, Renato. Lei de execução penal: anotada e interpretada. 3. ed. Rio de Janeiro: Lumen Juris, 2009.

MARCÍlIO, Maria Luiza (Org.). Declaração Universal dos Direitos Humanos: sessenta anos. Sonhos e realidades. São Paulo: Edusp, 2008.

MIRABETE, Julio Fabbrini. Execução penal. São Paulo: Atlas, 2004.

MORAES, Alexandre de. Direito constitucional. 19. ed. São Paulo: Atlas, 2006.

MORAES, Alexandre de. Direitos humanos fundamentais: teoria geral. 8. ed. São Paulo: Atlas, 2007.

PAGLIUCA, José Carlos Gobbis. Direito penal: legislação especial e execução penal. 2. ed. São Paulo: Rideel, 2008.

PASCHOAL, Janaina Conceição. Direito penal: parte geral. São Paulo: Manole, 2003.

PIOVESAN, Flávia. Temas de direitos humanos. 3. ed. São Paulo: Saraiva, 2009.

REALE Jr., Miguel. Instituições de direito penal: parte geral. 2. ed. Rio de Janeiro: Forense 2004. 
RELATÓRIO: Situação dos presídios brasileiros. Disponivel em: <http://www.camara.gov.br/cdh>. SÁ, Alvino Augusto de. Criminologia clínica e psicologia criminal. São Paulo: Revista dos Tribunais, 2007.

SECRETARIA DA ADMINISTRAÇÃO PENITENCIÁRIA DO ESTADO DE SÃO PAULO. Disponível em: <http://www.sap.sp.gov.br/common/unidades.html>.

TOURINHO FILHO, Fernando da Costa. Munual de processo penal. 10. ed. São Paulo: Saraiva, 2008. 